\title{
Religiosity in Slovakia: Structure, Dynamics, and Spatial Diversification
}

\author{
Tatiana Zachar Podolinská, Miroslav Tížik and Juraj Majo
}

https://doi.org/10.14712/25704893.2019.1

\begin{abstract}
Abstrakt: Religiozita je časovo a priestorovo podmienený klúčový sociálny fenomén s vel'kou vnútornou variabilitou. $\mathrm{V}$ článku sa zameriavame na výber najvýznamnejších ukazovatel'ov prejavov tohto javu v slovenskej spoločnosti. Prostredníctvom časových štatistických údajov s náznakmi niektorých štruktúrnych rozdielov v súčasnosti, poukazujeme na dynamiku a vel'kú priestorovú diverzifikáciu konfesionálnych pomerov na Slovensku. Výrazným formujúcim faktorom boli aj politické rámce regulujúce náboženský život - vztahy štátu a cirkví, ktorých variabilita $\mathrm{v}$ kontexte spoločensko-politických zmien bola nezanedbatel'ným determinantom vývoja religiozity a náboženského života. V analýze religiozity naznačujeme aj vnútorné aspekty religiozity meranej výberovými zistovaniami poukazujúcich na pestrost vnútorných prejavov viery a jej odlišnosti v porovnaní s meraním konfesionality v sčítaniach obyvatel'stva.
\end{abstract}

Klíčová slova: religiozita; Slovensko; diverzita; konfesionalita; sekularizácia; vztah štátu a cirkvi

\begin{abstract}
Religiosity represents a key temporaland spatial-based social phenomenon with great internal variability. In this paper, we focus on a selection of the most important indicators of this factor in Slovakian society. With the aid of temporal statistical data with some structural differences (such as age) in current society, we attempt to concentrate on the dynamics and great spatial diversification of denominational division in Slovakia. The Church and state relationship is another politically important factor which influences this social phenomenon. The variability of relationships within the social and political context and its transformations was a significant determinant influencing the religiosity and development of religious life. Moreover, even in today's mostly secularizing society, this relationship maintains its importance for the society. In the analysis of societal religiosity, we have to focus on the internal aspects of faith, measured by representative surveys that portray varieties of internal aspects of faith and their divergence from the censual measurement of denominational affiliation.
\end{abstract}

Keywords: religiosity; Slovakia; diversity; denominations; secularization; church-state relation

Received: 25 February 2019, Accepted: 13 May 2019

Published online: 31 January 2020

Tatiana Zachar Podolinská, senior research fellow, Institute of Ethnology and Social Anthropology of Slovak Academy of Sciences, Bratislava, Slovakia

E-mail: tatiana.podolinska@savba.sk

Miroslav Tí̌ik, senior research fellow, Institute for Sociology of Slovak Academy of Sciences, Bratislava, Slovakia

E-mail: miroslav.tizik@savba.sk

Juraj Majo, assistant professor, Department of Economic and Social Geography, Demography and Territorial Development, Comenius University in Bratislava, Slovakia

E-mail: juraj.majo@uniba.sk

(c) 2019 The Authors. This is an open-access article distributed under the terms of the Creative Commons Attribution License (http://creativecommons.org/licenses/by/4.0). 


\section{Historical overview}

Slovakia counts among many Eastern and Central European countries, in which Religious Studies, i.e. an academic approach to the study of religion was established relatively late. The reason for this was not merely the unfavourable ideological milieu under the Communist regime (1948-1989), but also the rather complicated history of Slovakia over the past two centuries and the associated process of the emergence of a modern Slovak nation. ${ }^{1}$

\subsection{From the mid-19th century until 1918}

From the 11th century up to 1918, 'Slovaks' lived mainly in a part of the Hungarian realm, politically referred to as Upper Hungary due to its geographical position. Stretching from the Early Middle Ages to the High Modern Era, the Slovak region lived under what in many aspects resembled a true political and cultural hegemony. ${ }^{2}$ We do not have relevant documents from this era on the religiosity of Upper Hungary; however, relevant data on religiosity can be obtained from one of the oldest official lexicons of settlements from 1773 (Lexicon universorum regni Hungariae ...). ${ }^{3}$ In February 1867, the monarchy of the Danube region was split into two parts: Austria and Hungary. This was the result and success of Hungarian ethno-national movements, but for Slovaks this political act resulted in an era of forced Hungarisation. ${ }^{4}$ The legal act from 1867 concerning the ethic issues of the newly constituted state anticipated a single unified nation - the Hungarian one. Based on this premise, Hungarian became the only official language. However, it was allowed to use the languages of ethnic minorities in primary and secondary education, in administration, during court hearings, and in religious life. Religiosity was not the focus of any of administrative or 'scientific' scrutiny until the first censuses appeared in the mid-19th century. Using the Atlas of Religiosity of Slovakia ${ }^{5}$ and the cartographic compilation of data concerning confessional belonging (based on censuses from the mid-19th century up to the last census in the Hungarian state in 1910), we can follow the dynamics of religious life in Slovakia (in terms of "confessional religiosity") (see Table 1).

The first modern census also covering the territory of present-day Slovakia in 1857 showed that despite the new act that made all confessions in Hungary equal with the Catholic Church (1848), more than $65 \%$ of its inhabitants claimed this confession, thus making Slovakia a predominantly Catholic region. Catholics were dominant in

See e.g. S. J. Kirschbaum, A History of Slovakia: The Struggle for Survival, New York: Palgrave Macmillan 1995, passim.

2 R. Holec, "Slovenskí katolíci medzi národom a štátom”, In T. Ivantyšynová (ed.), Národ - cirkev - štát, Bratislava: Spoločnost' pre dejiny a kultúru strednej a východnej Európy, Centrum pre európsku politiku, Historický ústav SAV 2007, p. 57-75.

3 B. ŠProcha and P. TIŠLIAR, Lexikóny obcí pre územie Slovenska I.: Vybrané úradné lexikóny z rokov 1920-2002, Bratislava: Infostat 2009, p. 8; J. MAJo, D. KusEndová, Náboženský atlas Slovenska, Bratislava: DAJAMA 2015, p. 4.

4 Holec, "Slovenskí katolíci mezi národom a štátom”, p. 57-75.

5 Majo and Kusendová, Náboženský atlas Slovenska, p. 9-21. 
Table 1: Data on religious affiliation according to the $1857-1910$ Censuses. ${ }^{6}$

\begin{tabular}{l|l|l|l|l|l|l}
\hline & $\begin{array}{l}\text { Census } \\
\mathbf{1 8 5 7}\end{array}$ & $\begin{array}{l}\text { Census } \\
\mathbf{1 8 6 9}\end{array}$ & $\begin{array}{l}\text { Census } \\
\mathbf{1 8 8 0}\end{array}$ & $\begin{array}{l}\text { Census } \\
\mathbf{1 8 9 0}\end{array}$ & $\begin{array}{l}\text { Census } \\
\mathbf{1 9 0 0}\end{array}$ & $\begin{array}{l}\text { Census } \\
\mathbf{1 9 1 0}\end{array}$ \\
\hline $\begin{array}{l}\text { Total number of inhabitants } \\
\text { (million) }\end{array}$ & 2.47 & 2.46 & 2.4 & 2.57 & 2.7 & 2.92 \\
\hline Catholic Church & $65.1 \%$ & $65.6 \%$ & $66.3 \%$ & $67.2 \%$ & $68.3 \%$ & $69.9 \%$ \\
\hline (million) & 1.6 & 1.6 & 1.6 & 1.7 & 1.9 & $>2.0$ \\
\hline Lutheran Evangelical Church & $15.5 \%$ & $15.9 \%$ & $15.3 \%$ & $14.8 \%$ & $14.2 \%$ & $13.5 \%$ \\
\hline & 382,000 & 391,000 & 377,000 & 382,000 & 394,000 & 395,000 \\
\hline Greek Catholic Church & $7.3 \%$ & $7.6 \%$ & $7.1 \%$ & $7.1 \%$ & $7.1 \%$ & $6.8 \%$ \\
\hline & 182,000 & 186,000 & 175,000 & 183,000 & 197,000 & 197,000 \\
\hline Reformed Church & $6.5 \%$ & $5.5 \%$ & $5.5 \%$ & $5.4 \%$ & $5.3 \%$ & $5.2 \%$ \\
\hline & 161,000 & 134,000 & 134,000 & 140,000 & 148,000 & 153,000 \\
\hline Jews & $5.5 \%$ & $5.5 \%$ & $5.7 \%$ & $5.4 \%$ & $5.0 \%$ & $4.8 \%$ \\
\hline & 136,000 & 134,000 & 140,000 & 138,000 & 140,000 & 139,000 \\
\hline Other confessions & $0.1 \%$ & $0.1 \%$ & $0.1 \%$ & $0.1 \%$ & $0.1 \%$ & $0.1 \%$ \\
\hline & 554 & 400 & 1,700 & 766 & $>1,000$ & $>2,000$ \\
\hline NONES & - & - & - & - & - & - \\
\hline & - & - & - & - & - & - \\
\hline
\end{tabular}

almost all regions of today's Slovakia (except for the Uh and Zemplín regions in the eastern part of Slovakia and towns like Modra - in 1857, 57\% of citizens declared to be Lutherans). Strong Jewish communities could be found in Nitra (32\%), Trenčín $(27 \%)$ and Bratislava $(14 \%){ }^{7}$

By the turn of the 19th and 20th centuries, the proportion of believers affiliated to the Catholic Church increased by $17 \%$. The strongest bastions of Catholicism were in the Trenčín region (more than $87 \%){ }^{8}$ Lutherans faced stagnation in terms of numbers. The Greek Catholic Church reported an internal increase of 5\%. The strongest influence of this confession was observed in the Zemplin (41\%), Uh (40\%) and Šariš (31\%) regions. ${ }^{9}$ The Reformed Church grew rapidly in this period, with an $11 \%$ increase in believers. The Orthodox Church counted only 1,000 individuals; there was, however, a significant trend of growth.

\subsection{Religiosity, Church, and State (1918-1989)}

The birth of the Czechoslovak Republic was not only due to a success of ethno-national ambitions and more than 60 years of political struggle, but it was also an im-

6 Compiled by T. Zachar Podolinská, based on Majo and Kusendová, Náboženský atlas Slovenska, p. 8-19. The Census of 1869 (at the level of villages) was published after the revision of L. Sebők in 2005, but some of the dataform the Abov region is incomplete. Majo and KusEndová, Náboženský atlas Slovenska, p. 11.

7 Majo and Kusendová, Náboženský atlas Slovenska, p. 35.

8 Majo and KusEndová, Náboženský atlas Slovenska, p. 36-37.

9 Majo and Kusendová, Náboženský atlas Slovenska, p. 37. 
portant breaking point in terms of the postulation of religious freedom and a new order of negotiation between the Church and the State. Not surprisingly, because of the strong visibility of the conservative Catholic Church on the side of the Habsburg dynasty under the former regime, many political parties included the separation of Church and State into their electoral programme. The first draft of the new constitution included such a paragraph. Yet, due to the complicated and different situation on the Slovak and Czech sides, the requirement for separation of Church and State in the first republic of Czechs and Slovaks was not included in the text of the new Constitution, as approved in $1920 .{ }^{10}$ Religious issues were so complicated to negotiate that finally there was no single paragraph concerning or moderating Church and State relations. The key Article 124 of the Constitution made all confessions equal before the law. Article 121 of the Constitution guaranteed not only religious freedom but also the freedom to have no church affiliation or confession, which means the freedom of one's religiosity or irreligiosity. According to the Census in 1921, there were 725,000 people without confession in Czechoslovakia.

In 1926, the Congruation Act was passed (Act No. 122/1926). This act distinguished between the so-called congruated and subsidised churches and religious communities. Within the territory of the Czech Republic and Moravia, only the Catholic Church (all three rites) and the Orthodox churches were 'congruated'. In Slovakia and Ruthenia, the Catholic Church (all three rites), the Lutheran Evangelical Church, the Reformed Church, the Orthodox Church, and the Jewish religious communities were 'reciped' ('recognized'). The minimum 'congruas' (i.e. state contributions) were 9,000 Czechoslovak crowns per year. In sum, 'recognised churches' received 130-150 million Czechoslovak crowns per year from the state; two thirds of this sum were granted to the Catholic Church. ${ }^{11}$ Negotiations between the newly constituted republic and the Vatican were launched in 1920. In 1928, the document Modus Vivendi was initialled.

As far as the religious situation in the Czechoslovak Republic is concerned, the atmosphere and the public discourse were very different. The importance of the Catholic Church in the Czech part of the Republic visibly and notably decreased. The Slovak part faced a completely opposite trend - the Catholic Church reported an internal increase in the number of believers by almost $25 \%$, with a $72 \%$ share in the general population. In some regions of Slovakia, the proportion of Catholic believers exceeded 90\% (Kysucké Nové Mesto 99\%). In 1930, the least Catholic region of Slovakia was the Medzilaborce district (9\%). ${ }^{12}$ As for nationality, $76 \%$ of Catholic believers declared Slovak ethnicity, $17 \%$ the Hungarian one and only $5 \%$ declared German ethnicity in $1930 .^{13}$

\footnotetext{
${ }^{10}$ L. Hubenák, “Církve a náboženské společnosti v Československu 1918-1938”, Prometheus - Časopis pre občiansku spoločnost' a humanismus III (4, 2007): p. 23-25.

${ }^{11}$ HubEnÁk, "Církve a náboženské společnosti v Československu 1918-1938”, p. 23-25.

${ }^{12}$ Majo and Kusendová, Náboženský atlas Slovenska, p. 37.

${ }^{13}$ Majo and Kusendová, Náboženský atlas Slovenska, p. 37.
} 
Table 2: Data on religious affiliation according to the 1921-1950 Censuses. ${ }^{14}$

\begin{tabular}{l|l|l|l|l}
\hline & Census 1921 & Census 1930 & Census 1940 & Census 1950 \\
\hline Total number of inhabitants (million) & $>3.0$ & 3.3 & 2.6 & 3.4 \\
\hline Catholic Church & $71.0 \%$ & $71.8 \%$ & $74.1 \%$ & $76.2 \%$ \\
\hline (million) & 2.1 & 2.3 & 1.9 & 2.6 \\
\hline Lutheran Evangelical Church & $12.8 \%$ & $12.1 \%$ & $14.3 \%$ & $12.9 \%$ \\
\hline & 383,000 & 400,000 & 388,000 & 443,000 \\
\hline Greek Catholic Church & $6.4 \%$ & $6.4 \%$ & $6.9 \%$ & $6.6 \%$ \\
\hline Reformed Church & 190,000 & 211,000 & 183,000 & 225,000 \\
\hline Jews & $4.7 \%$ & $4.3 \%$ & $0.5 \%$ & $3.2 \%$ \\
\hline Orthodox Church & 140,000 & 141,000 & 12,000 & 111,000 \\
\hline & $4.5 \%$ & $4.1 \%$ & $3.2 \%$ & $0.2 \%$ \\
\hline Other confessions & 135,000 & 135,000 & 86,000 & $>7,000$ \\
\hline & & & $0.3 \%$ & $0.2 \%$ \\
\hline NONES & & & & $<8,000$ \\
\hline & $0.6 \%$ & $1.5 \%$ & $0.2 \%$ & $0.3 \%$ \\
\hline Sin data/no answer & 17,000 & 48,000 & & \\
\hline & $0.2 \%$ & $0.5 \%$ & $0.2 \%$ & $0.3 \%$ \\
\hline & $<7,000$ & 16,000 & & $>9,000$ \\
\hline & & & & $0.1 \%$ \\
\hline
\end{tabular}

In 1921, Czechoslovakia had 13.5 million of inhabitants ( 3 million in Slovakia); 724 thousand of them declared to be 'without confession' (hereinafter referred to as 'nones'). In the Czech part, it was 5.32\%, whereas in Slovakia only 0.23\%. In 1930, the total population reached 14.7 million inhabitants, 854 thousand of them being nones. The distribution of nones was remarkably different: $5.8 \%$ in the Czech part, and only $0.51 \%$ in the Slovak one. After 1945 , the situation changed dramatically; 2.9 million Czech Germans were evicted and Czechoslovakia lost Ruthenia. As a consequence, the total number of inhabitants fell to 12.7 million; 766 thousand of whom were 'nones'.

Between 1940 and 1950, the religious development of the Catholic Church was positive and stable. In terms of the number of believers, the proportion of Catholics in the Slovak population reached $74 \% .^{15}$ There was a $10 \%$ internal increase of believers in the Catholic Church in Slovakia in 1930-1950. As far as Lutherans are concerned, only $3 \%$ of them resided outside the new borders after the Vienna arbi-

${ }^{14}$ Compiled by T. Zachar Podolinská, based on Majo and KusEndová, Náboženský atlas Slovenska, p. 20-27. Due to the Vienna Arbitration, the total number of inhabitants decreased dramatically in 1940. There were approximately 901,000 people within the territory occupied by Hungary $(70 \%$ of them were affiliated to the Catholic Church, followed by the Reformed Church, Greek Catholics, Jews and Lutherans). Majo and Kusendová, Náboženský atlas Slovenska, p. 25.

15 MAjo and Kusendová, Náboženský atlas Slovenska, p. 38. 
tration. The proportion of Lutherans in Slovak population increased to $15 \%{ }^{16}$ The Greek Catholic Church reported a 7\% increase in Slovakia (1940 to 1930). In 1950, before its abolition, it faced a $6 \%$ internal increase and its share in the Slovak population reached 6.6\%. The strongest Greek Catholic districts were Medzilaborce (86\%) and Svidník (83\%).

The change of the border had a dramatic effect on the Reformed Church. Ten years after 1938, the number of the Reformed decreased by $91 \%$ to $0.5 \%$ with a total number of believers of 13,000. Trebišov and Michalovce, and Bratislava with 1,000 believers remained the strongest districts. The most dramatic change, however, was observed among Jews. Due to the Vienna arbitrations, deportations and emigration of Jews during and after WWII, there was a 95\% decline (1950 against 1940). In 1950, only 7,500 Jews lived in Slovakia compared to 87,000 in 1940 and $89 \%$ of settlements in Slovakia had no Jewish population. The Orthodox Church faced a $18 \%$ internal decline. In 1950, their total number increased and reached 8,000 believers residing mostly in the Eastern part of Slovakia. ${ }^{17}$

During the first phase of the creation of the post-war Czechoslovak republic, under the reign of the National Front coalition government, the representatives of the Catholic Church perceived the Church and State relations positively and wished this to continue in the future. For example, on 15 November 1945, led by Archbishop of Prague Josef Beran, they claimed to be a part of the 'building of our State' in the Czech part of the republic. 'The Church is willing to collaborate in the construction of the Republic'. On 13 May 1946, the diplomatic contacts between the Vatican and the Czechoslovak Republic were restored. Internuncius Xáber Rither, known for his negative attitudes towards fascism and Nazism, returned as the representative of the Holy See. Doctor Josef Beran, who was detained by the secret police during the Protectorate period and deported to Dachau, was appointed as the new archbishop.

The situation in Slovakia was different from Czech lands for many reasons. After World War II was over, the tensions in the relations between the Catholic Church and the Czechoslovak State culminated in Slovakia. Back during the Uprising (1944), there were many cases of open confrontation between insurgents and Church representatives. Because of its support provided to the Hlinka Slovak People's Party, the Catholic Church was also blamed for supporting fascism.

The Slovak National Council (SNC), which had no Catholic representatives, nationalised all schools in Slovakia through its Fifth Regulation, from childcare centres and shelters to universities. This regulation entered into effect on 06 September 1944, i.e. less than a week after the SNC came out from the underground in the areas controlled by partisans. The SNC re-approved this resolution on 16 May $1945 .^{18}$

Before the May elections in 1946, the Slovak Catholics made an agreement with the predominantly Protestant-oriented leadership of the Democratic Party. This party

${ }^{16}$ MAjo and Kusendová, Náboženský atlas Slovenska, p. 39.

17 MAjo and KusEndová, Náboženský atlas Slovenska, p. 39.

${ }^{18}$ The protests by Slovak bishops against this decision resulted in the arrest and imprisonment of, for example, Bishop Ján Vojtaššák. 
won $62 \%$ of the votes in the elections, while the Communists less than $30 \%$, which was radically different picture than in Czech lands where Communists won the elections. ${ }^{19}$

The situation in Slovakia radically changed after the Communists came into power in February 1948. At the beginning, the leading Communist functionaries sought to bring the Catholic Church under their control through an agreement with the bishops or to obtain the co-operation of some of them. On the outside, the government was willing to negotiate, but the state authorities were constantly restricting the Church activities. For example, the National Front's Action Committee (NFAC) issued a declaration on the freedom of religion and, at the same time, it appointed a church secretary for each action committee. In March 1948, most Catholic magazines were discontinued, which was justified by a shortage of paper. This was shortly followed by a regulation ordering the removal of crosses from schools and a dismissal of all teachers who were members of religious orders. Religious education at secondary schools was cancelled or radically reduced. The Church was also affected by Act No. 44/1948 Coll. on Land Reform and Government Regulation No. 1/1948 Coll. on the Revised First Land Reform under which the Church lost all its agricultural assets. Even more damage was caused by Act No. 95/1948 on the Single School of 21 April 1948 which curtailed the activities of church schools. After the May elections, the Bishops' Assembly hoped to save church schools, provided that the bishops showed their loyalty to the new President of the Republic, Klement Gottwald. The Archbishop of Prague, Doctor Josef Beran, held a Te Deum ceremony in the St. Vitus Cathedral in Prague on 14 June 1948 in honour of the President in the presence of the CSR Government.

The next period of 1949-50 was crucial when it comes to the future of the Church in Czechoslovakia. This period laid the fundaments of the state control of Churches. This was followed by a series of significant interventions against the Church; the publishing of Christian magazines was banned, and publishing houses were nationalised. In the Declaration of the Central Committee of the Communist Party of Czechoslovakia of 25 April 1949, the Church was clearly defined as an 'enemy' which must be brought under the legal control of the state apparatus. This Declaration also demanded the 'separation of the Church from Rome' and the creation of a 'national Church'. On 10 June 1949, the 'Catholic Action' was founded under the leadership of priest Jozef Plojhar. Only 67 priests and an unidentified number of lay persons participated at the founding congress. The Bishops' Assembly condemned its establishment by a pastoral letter which was expected to be read in all churches on Sunday, 19 June. This 'action' was officially condemned by the Vatican's excommunication decree on 20 June 1949.

${ }^{19}$ In the Czech lands, the Communist Party achieved the best results in the districts from which the original German population was displaced (the highest proportion of displaced persons was $70.45 \%$ in the Tachov district). Despite the fact that in Slovakia, the Democratic Party won the elections with the majority of votes $(61.43 \%)$, the victory of the Communist Party in the Czech lands meant the Democratic Party was abolished and the Communist Party gained power throughout the whole of Czechoslovakia (source: https://www.fronta.cz/dotaz/volby-1946 -vitezstvi-ksc-a-odsun-nemcu,accessedon August 26, 2019). 


\subsection{0-1989 Period}

The census of 31 March 1950, at the very beginning of the socialist era in Slovakia, was the last one for a long time to collect answers concerning confession. According to this census, Czechoslovakia had 12,338,450 of inhabitants; 3,442,317 of whom lived in the Slovak part of the republic. The Catholic Church claimed $74.42 \%$ of affiliates in the Czech part of the country and $76.2 \%$ in Slovakia.

In 1951, according to the report from the Ministry of the Interior, the Czechoslovak Republic had 9 million Catholics; 400,000 Evangelicals (Lutherans); 100,000 Calvinists; 10,000 Adventists; 8,000 Methodists; 8,000 members of the Unity of Brethren; 2,000 Unitarians; 8,000 Baptists; 900,000 members of the Czechoslovak Church; and 250,000 members of the Orthodox Church. The Greek-Catholic Church was banned in Czechoslovakia on 28 April 1950.

By Government Regulation No. 112/1950 of 14 July, the Communist government abolished all diocesan seminars and religious theological universities and founded the only theological university in Slovakia - the Faculty of Roman Catholic Theology of Cyril and Methodius in Bratislava under the supervision of the State Authority for Church Matters. The number of seminarists decreased by $90 \%$.

The next period was characterised by arrests of leading church representatives. On 2-15 January, the State Court in Bratislava sentenced the 74-year-old bishop Ján Vojtaššák to 24 years in prison and a fine of 500,000 crowns; and the 66-year old bishop Doctor Michal Buzalka and 63-year bishop Pavel Gojdič, OSBM, were given a life sentence. This political atmosphere resulted in Vatican diplomats leaving and many church representatives moving abroad.

On 11 July 1960, a new Constitution was adopted, calling the country the Czechoslovak Socialist Republic. According to the 1961 census, the population of Czechoslovakia was 13,745,577 as of 1 March. Slovakia had 4,174,046 inhabitants, of which 3,560,000 claimed the Slovak ethnicity (519,000 the Hungarian one).

\section{The Post-Communist Era and Recent Trends in Religiosity in Slovakia}

The socialist period did not favour the collection, analysis, and publishing of data about religious affinity and this topic became taboo for several decades after the 1950 census. Historical data about churches was partly published in the Atlas of Czechoslovak History ${ }^{20}$ in the form of a map of the Roman Catholic, Greek Catholic, Evangelical of Augsburg Confession, Reformed Christian, and Jewish Church administration in 1848 . The revised version of this atlas concerning the Slovak territory was published in the Ethnographic Atlas of Slovakia ${ }^{21}$ of 1990 and a major part of it was produced back during the socialist period. The data on the religious structure of the

${ }^{20}$ Atlas československých dějin, 1965, Praha: Ústř̌edí správy geodezie a kartografie.

${ }^{21}$ Etnografický Atlas Slovenska, B. Filová, S. Kovačevičová (eds.) (1990), Bratislava: Národopisný ústav Bratislava a Slovenská kartografia. 
population remained unpublished in a comprehensive cartographic form until the end of the millennium.

In 2000, a team of authors led by geographer Štefan Poláčik published a unique Atlas of Churches, Religious Communities and Religiosity in Slovakia (Ecumenical Atlas). ${ }^{22}$ Besides a basic description of the registered churches and religious communities, the atlas contains maps of the territorial administration and figures based on the 1991 census. A new national atlas - The Atlas of the Landscape of the Slovak Republic - was published in the beginning of the new millennium, in 2002. ${ }^{23}$ The chapter on population includes maps of the confessional structure of towns and municipalities in 1991 and districts in 1880. In addition, the atlas shows the results of the 2001 census and data on the religious structure of the population per district. The tradition of publishing religious atlases continued in 2005 with the Atlas of the Catholic Church in Slovakia under the guidance of Viliam Judák and Štefan Poláčik. ${ }^{24}$ Besides detailed information on the life of both Catholic Churches in Slovakia, as depicted on maps, the atlas also contains basic maps for other more numerous churches and religious communities according to the census conducted in 2001. The so-far last comprehensive work among religious maps is the mono-confessional Historical Atlas of the Evangelical Church of the Augsburg Confession in Slovakia, published in 2011 under the guidance of Dagmar Kusendová and Mojmír Benža. ${ }^{25}$ The authors of the Demographic Atlas of the Slovak Republic from 2014, which mainly reflects the data obtained from the 2011 census, present the basic results concerning the most numerous churches, religious communities and people claiming no confession. ${ }^{26}$

According to the representative international survey European Values Study (EVS) conducted also in Slovakia in 1991 and 1999, there was a rapid rise in the number of believers in Slovakia in the first decade after the fall of Communism; from around $63.5 \%$ in the early 1990s (EVS 1991) to around 76\% in the late 1990s (EVS 1999). ${ }^{27}$ This 'religious turn' can be interpreted as a result of the post-Communist climate. The old institutional framework was completely dismantled, including all its 'securities'. The civil society was in its 'embryonic' state with a virtual absence of an intermediary layer of NGOs; the nuclear family and its values were in a deep crisis. Another very important limitation was economic: it was a period of extreme material hardship

22 PolÁčIK, Š., Atlas cirkví, náboženských spoločnostía religiozity Slovenska, Bratislava: Chronos 2000.

${ }^{23}$ Atlas krajiny Slovenskej republiky, 2002, Bratislava: Ministerstvo životného prostredia.

${ }^{24}$ Judák, V., Poláčı́, Š. (eds.), Atlas Katolíckej cirkvi na Slovensku, Bratislava: Lúč 2005.

${ }^{25}$ KusendovÁ, D., BenžA, M. (eds.), Historický atlas Evanjelickej cirkvi augsburského vyznania na Slovensku, Liptovský Mikuláš: Tranoscius 2011.

${ }^{26}$ BLEHA, B., VAŇO, B., BAČíK, V. (eds). Demografický atlas Slovenskej republiky. Bratislava: Geografika 2014.

${ }^{27}$ In this regard, however, it is necessary to comment on the data from 1991: the number of believers was slightly underestimated because a different method of measurement was employed. EVS - Výskum európskych hodnôt 1991 [EVS - European Values Study 1991], [online], SASD, EVS 1991, accessed July 10, 2019, available online at http://sasd.sav.sk/sk/data_katalog_abs .php?id=sasd_1991001 as in 1999 "EVS - Výskum európskych hodnôt 1999" ["EVS - European Values Study 1999"], [online], SASD, EVS 1999, accessed July 10, 2019, available online at http://sasd .sav.sk/sk/data_katalog_abs.php?id=sasd_1999002. 
after the downfall of the socialist planned economy. Unsurprisingly, the period of 'inflated expectations' and 'freedom of self' was followed by a period of 'normative confusion'. To get through these turbulent times, people were searching for their lost 'security' and a new 'protective umbrella'. Under these conditions, the historically attested tradition of religion and a credible institutional representative as embodied by the traditional church became the 'majority option'. Our case showed another very important trend. In Slovakia, the traditional Church adopted the position of a 'Communist martyr' and (at least in the first post-Communist decade) profited very much from the social capital of this position. In addition, the Church privatised the role of the 'housekeeper' of the national tradition.

The concept of 'traditional' religion that has its historical merits and privileges became a common device for structuring religious policy and the legislative debate. This turbulent development and the flexible strategy of the Roman Catholic Church resulted (at least) in a 'numeral' re-birth of traditional Catholicism in Slovakia. Consequently, Slovakia (together with Poland) is frequently referred to as one of the most traditional 'bastions' of Catholicism in Europe. ${ }^{28}$

According to the interim analysis of the first and second waves of the EVS (EVS 1991 and EVS 1999), the first post-Communist decade was indeed a decade of religious turn in Slovakia. Religious faith was strengthened along with the church-attendance rate and general confidence in the Church. ${ }^{29}$ In 1991, 'prevailing confidence' in the Church was reported to be $49 \%$ for Slovak respondents. In 1999, there was a $16 \%$ increase and the number reached $64.8 \%$. Nevertheless, hand in hand with these pro-Church attitudes, people began to declare that the Church should focus more (or merely) on religious and spiritual issues. Hence, religious influence was endorsed 'only' in those cases where it was kept within the pressure limits and did not interfere directly into the sphere of politics. According both waves of EVS tolerance towards the co-existence of people of various religions or without religion was higher than it was in the early 1990s.

Based on the figures from the latest surveys, we can follow the religious dynamics of the second post-Communist decade in comparison with the first one. Both the EVS $2008^{30}$ and ISSP $2008^{31}$ results indicate that the Church's responses to spiritual, moral, and family issues in Slovakia were seen as adequate in numbers exceeding the European average. In 2004, the national survey Collective Identities in Contemporary Slovakia $^{32}$ revealed that $34 \%$ of respondents explicitly support decreasing the power

${ }^{28}$ For a clarification of the context, see Part 4 of the study.

${ }^{29}$ V. KRIVÝ, "Hodnotové orientácie a náboženské prejavy slovenskej verejnosti v 90. rokoch”, Sociológia 33 (1,2001), p. 14.

30 "EVS - Výskum európskych hodnôt 2008" [EVS - European Values Study 2008] [online], SASD, EVS 2008, accessed [10. 7. 2019], available online at http://sasd.sav.sk/sk/data_katalog_abs .php?id=sasd_2008001.

31 “ISSP Náboženstvo 1998” [ISSP Religion 1998] [online], SASD, ISSP 1998, accessed [10. 7. 2019], available online at http://sasd.sav.sk/sk/data_katalog_abs.php?id=sasd_1998001.

32 "Kolektívne identity na súčasnom Slovensku 2003" [Collective Identities in Contemporary Slovakia 2003] [online], $S A S D$, accessed [10. 7. 2019], available online at http://sasd.sav.sk/sk/data _katalog_abs.php?id=sasd_2003001. 
of the Roman Catholic Church in the public space and perceive the rising influence of the Church negatively. Among higher-educated respondents, this figure reached up to $45.8 \%{ }^{33}$ In the same survey, $72.6 \%$ of respondents agreed with the statement that 'Christian values should be interpreted in a more modern way than the Church in Slovakia used to do'.

If we follow the dynamic of religiosity in Slovakia through the lens of the last three censuses, the religious situation seems to be very stable, almost untouched by the dramatic political and economic changes in society during the transition era (Table 3).

Table 3: Data on religious affiliation according to the 1991-2011 Censuses. ${ }^{34}$

\begin{tabular}{l|l|l|l}
\hline & Census 1991 & Census 2001 & Census 2011 \\
\hline Total number of inhabitants (million) & 5.2 & 5.35 & 5.39 \\
\hline Catholic Church & $60.4 \%$ & $68.9 \%$ & $62.0 \%$ \\
\hline (million) & 3.1 & 3.7 & 3.3 \\
\hline Lutheran Evangelical Church & $6.2 \%$ & $6.9 \%$ & $5.9 \%$ \\
\hline & 326,000 & 372,000 & 316,000 \\
\hline Greek Catholic Church & $3.4 \%$ & $4.1 \%$ & $3.8 \%$ \\
\hline & 178,000 & 219,000 & 206,000 \\
\hline Reformed Church & $1.6 \%$ & $2.0 \%$ & $1.8 \%$ \\
\hline Orthodox Church & 82,000 & 107,000 & 98,000 \\
\hline & $0.7 \%$ & $0.9 \%$ & $0.9 \%$ \\
\hline Other confessions & 34,000 & 50,000 & 49,000 \\
\hline & $0.6 \%$ & $1.1 \%$ & $1.5 \%$ \\
\hline NONES & 30,000 & 50,000 & 79,000 \\
\hline & $9.8 \%$ & $13.0 \%$ & $1.4 \%$ \\
\hline Sin data/no answer & 515,000 & 697,000 & 725,000 \\
\hline & $17.4 \%$ & $3.0 \%$ & $10.6 \%$ \\
\hline & 917,000 & 160,000 & 571,000 \\
\hline & & & \\
\hline
\end{tabular}

For a better understanding of the present state of religiosity in Slovakia, it is important to describe the political and historical context of the changes, mostly after 1989. We can subsequently launch a deeper investigation into the various types of religiosity in Slovakia.

The situation in which the Slovak Republic found itself in 1993 can be characterised as a struggle with three traditions. The first problem was the way we deal with and find an attitude towards the period of the last 40 years of the state-socialism (Communist regime), which declared itself a materialist order. The fall of the rule of the Communist party was one of the issues related to the legitimisation of the new

${ }^{33}$ V. KRIVÝ, Kolektívne identity na súčasnom Slovensku, Bratislava: ÚEt SAV, SÚ SAV 2004, p. $37,67$.

${ }^{34}$ Compiled by T. Podolinská, based on the MAJo and KusEndová, Atlas of Religiosity of Slovakia, 28-33. 
order. As a result, the official rhetoric of the new Slovak Republic rejected continuity with this era. ${ }^{35}$ The second problem in the discussions about the character of the new state was the separation of the Czech and Slovak Federative Republic, causing a rupture in the shared Czechoslovak tradition and self-definition outside the heritage of the united federative republic and against the Czech Republic became prevalent. The third important factor in the search for legitimacy of the new state and new regime was the very specific temporality of Slovak citizens. Historian L'. Lipták called it a 'new temporality'. ${ }^{36}$ According to his hypothesis, the generation that reached the retirement age in 1993 had experienced five political regimes throughout their lives, with revolutions, territorial, state, and political changes, as well as new economic systems. Of the five regimes that this generation experienced, only two can be considered democratic.

Not only in the European context; at the beginning of the 21st century Slovakia can be considered one of moderately religious countries - countries with a high level of declarative religiosity and an average level of church attendance - together with the United States and Spain. ${ }^{37}$ The 25 -year period of transformation of the relationship between religion and the state in Slovakia since 1989 can be divided into five phases. ${ }^{38}$

The first period refers to the years of the common Czech and Slovak Federative Republic (1990-1992). This period can be called the period of creating an independent religious field in Slovakia (religious field as defined by Bourdieu) ${ }^{39}$ during which religious freedom was one of the most crucial issues. But it was still in the frame of a united Czechoslovakia with some small differences between Czechs and Slovaks, due to Czechoslovakia's federal character. In addition, religious freedom and the economic and legal independence of religion from the state were guaranteed.

The second phase (1993-2000) is characterised by the creation of state authorities in the new Slovak Republic. The social importance of religion in the symbolic character of the state increased, and the basic rules of the religious field were strengthened. The religious field as a symbolic space of the State was Christianised, and Christianity became a nation-forming and state-forming principle. In this phase, the positions of the Catholic and Lutheran Churches became dominant.

The third phase (2000-2004) began with the adoption of the Basic Treaty between the Slovak Republic and the Holy See in 2000. Roman Catholicism, as the doxa

${ }^{35}$ M. TížIK, “Out of Civil Religion in Slovakia after 1993”, In E. RÉVAY and M. Tomka (eds.), Church and Religious Life in Post-Communist Societies, Pázmány Társadalomtudomány 7, Budapest: Piliscsaba 2007, p. 183-207.

${ }^{36}$ L'. Lipták, Changes of Changes: Society and Politics in Slovakia in the 20th Century, Bratislava: Historical Institute of Slovak Academy of Sciences 2002, passim.

${ }^{37}$ M. Tížž, "Religion and National Identity in an Enlarging Europe", In Franz HöLlinger and MARKus HAdLER (eds.), Crossing Borders, Shifting Boundaries: National and Transnational Identities in Europe and Beyond, Frankfurt-on-Main: Campus Verlag 2012, p. 101-123.

${ }^{38}$ M. Tížıx, "Religion and the State after the Fall of State Socialism in Central and Eastern Europe", In Religious Diversity Today: Experiencing Religion in the Contemporary World, vol. 3: Religion Transforming Societies and Social Lives, Santa Barbara: Praeger 2015, p. 169-202.

${ }^{39}$ P. Bourdieu, "Genèse et structure du champ religieux", Revue française de sociologie $12(3,1971)$, p. 295-334. 
of the religious field, was strengthened, and the presence of dominant actors of the religious field in terms of power was stabilised.

The fourth phase (2004-2009) was marked by Slovakia's accession to the European Union in 2004, bringing about a halt to the increasing influence and power of the Catholic Church in the field of power and within the symbolic space in Slovakia. This was manifested openly in 2005 through a governmental crisis, which resulted in early elections. This crisis related to disputes over issues promoted by the Catholic Church, which was seeking a treaty with the Holy See on the Right to Conscientious Objection, meant to guarantee the right of public actors not to engage in activities that run counter to the teachings of the Church. On the one hand, this highlighted the presence of the Catholic Church within the power segments of the state; on the other hand, it also demonstrated the Church's inability to enforce an agreement unilaterally advantageous to it against the interests of the state, which protected its existing (restricted) monopoly over symbolic violence and respected several international obligations toward the European Union and other international actors.

The fifth and latest well-defined phase began with the introduction of the euro as a currency in 2009. This phase overlaps with the advent of the economic and financial crisis, which has made Europe-wide issues less important and strengthened nation states as actors in international politics. In terms of the relations between the State and religion in Slovakia, this period brought enforcement of religious institutions as important public actors in multiple spheres of political life in the country. In 2012, there were certain indications suggesting the potential beginning of a new, sixth phase in the relations between the State and Churches, as the largest Churches have begun to be integrated in the power field in new ways. For example, some parts of the Churches, including the Catholic Church, became a part of the Eurosceptic camp and supported the initiatives to leave the European Union in the summer of 2016.

All these changes in Church and State relations took place in a society whose religious structure can be considered stable, with a long history and in which the majority of the population belonged to the Catholic Church alongside a significant minority of non-Catholic Churches.

The newly emerging state placed an increased symbolic importance on religion, and specifically on the Christian religion as a source of symbolic capital and constituent power. Apart from that, the two dominant actors, the Catholic and Lutheran Churches, were granted special privileges within the religious field through a number of measures that led to the formation of the Catholic-Lutheran asymmetrical dualism, with the Catholic Church serving as the dominant actor of the two within the emerging field of power. ${ }^{40}$ Still, all registered churches in Slovakia (there were 15 in 1993 and 18 in 2016) were part of the religious field and the core included all those churches that received state subsidies and participated in discussions regarding the conditions for this subsidy (this included 12 of the 15 registered churches in 1993).

${ }^{40}$ M. TížIK, Náboženstvo vo verejnom živote na Slovensku: Zápasy o ideový charakter štátu a spoločnosti, Bratislava: Sociologický ústav SAV 2011, p. 339. 


\subsection{Data on religiosity}

Various data can be used in the investigation of religiosity:

\section{A) Censuses}

Data from censuses have been helping us understand the changes in the religious structure of Slovakia for more than 100 years. For the moment, the data on religious affiliation from the censuses conducted in 1940, 1960, 1970 and 1980 is missing. But in general, censuses can show a general trend in religious changes in Slovakia. More information on Slovakia's religious structure based on census data is available in tables $1,2,3$.

\section{B) Surveys}

Except for the census data that is already available, there have been many surveys that have been in some way related to the measurement of religiosity. The first survey in Slovakia was conducted in 1998 and the last one in 2016. Most of them are freely accessible online through the Slovak Archive of Social Data $(S A S D)^{41}$

There are various kinds of surveys, which are useful for understanding religiosity in Slovakia:

- National surveys (carried out only in Slovakia):

- Word View Attitudes in Slovakia 1968 (SPOS 1968)

- Equality and Minorities in Slovakia 2008

- Democracy and Citizens in Slovakia (DOS 2014)

- International comparative surveys (most of them comparable within V4 countries):

- European Values Study - EVS (1991, 1999, 2008, 2017)

- World Values Survey - WVS (1990, 1998, 2017 together with EVS)

- International Social Survey Programme - ISSP (Religion 1998, 2008 and National Identity 1995, 2003, 2015, Citizenship and others)

- European Social Survey - ESS

- Aufbruch 1997, 200742

For a basic overview of religious changes in Slovakia, a comparison between the years 1968 and 2014 can be useful. The survey on religiosity conducted in 1968 was the first one in the history of Slovakia, and the survey of 2014 replicated all the questions used in 1968, which offers a unique comparison for the purposes of an analysis of changes in religiosity.

\subsection{Changes in religiosity in Slovakia}

For further characteristics, a comparison of the data from two surveys will be used as a case study of the dynamics of religiosity in Slovakia. The surveys carried out in

${ }^{41}$ Slovenský archív sociálnych dát (SASD) [online] [Slovak Archive of Social Data], accessed [10.7. 2019], available online at http://sasd.sav.sk/sk.

${ }^{42}$ The results from all participating countries are available on-line at their specific web pages. 
$1968^{43}$ and $2014^{44}$ can help provide a deeper description of the multi-dimensional character of religiosity and show basic trends in religious change. Three basic dimensions of religiosity, used in most surveys (not only in SPOS 1968 and DOS 2014), can be distinguished: 1. religious affiliation (with or without religion), 2. religious practice (church attendance, frequency of prayer, reading of religious books, pilgrimages, etc.), 3. religious beliefs (belief in God, in church teaching, spiritual entities, etc.).

Both surveys (SPOS 1968 and DOS 2014) also investigated the attitudes of respondents towards other religious beliefs and towards the relation of religion and churches in the public space.

\subsubsection{Religious affiliation in Slovakia}

The survey data from SPOS 1968 and DOS 2014 show similar tendencies as the census data. A kind of stability of religious landscape can be observed in the last half of the century, with a growing group of people without religious affiliation and a more significant decline in the number of people affiliated with Protestant churches (Fig. 1).

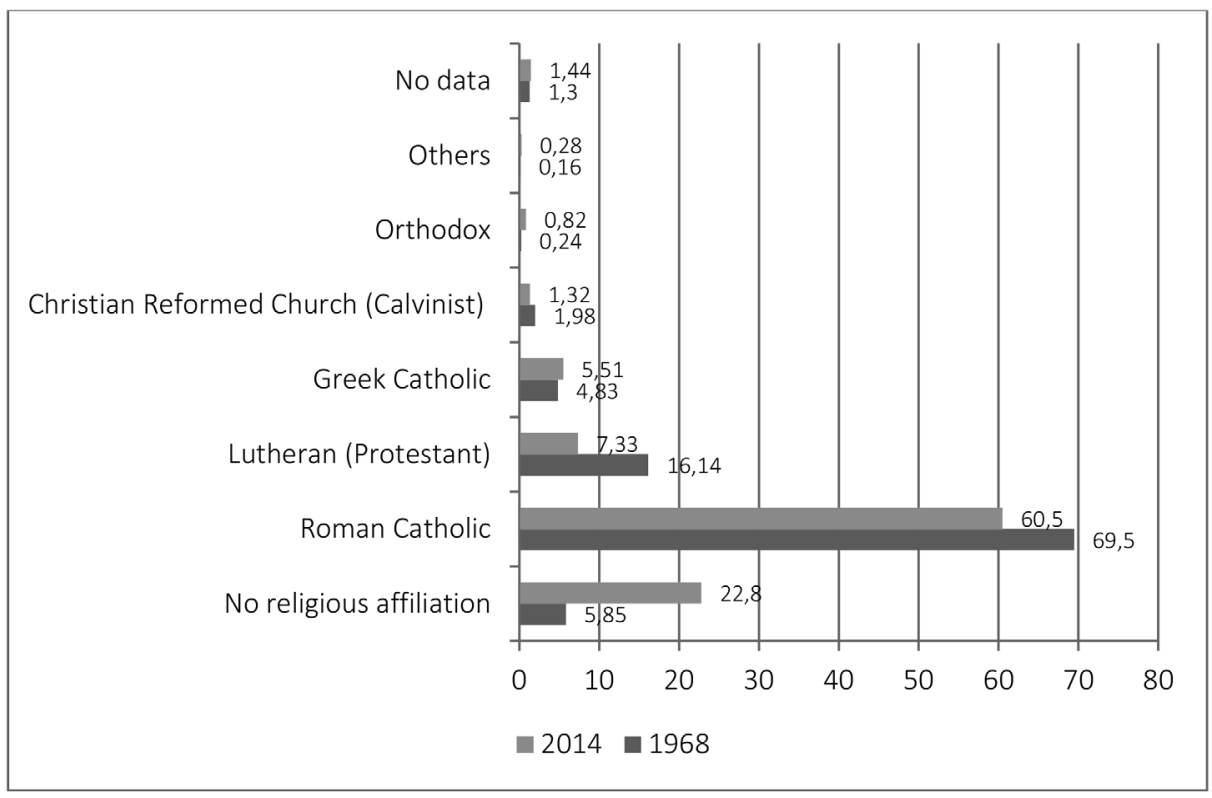

Figure 1: What is your religious affiliation?

Compiled by M. Tížik 2017, SPOS 1968, DOS 2014.

43 "O svetonázorových postojoch obyvatel'ov Slovenska 1968" [Word View Attitudes in Slovakia 1968] [online], SASD, SPOS 1968, accessed [10.7. 2019], available online at http://sasd.sav.sk/sk /data_katalog_abs.php?id=sasd_1968002.SPOS 1968.

44 "Demokratickost' a občania na Slovensku" [Democracy and Citizens in Slovakia], SASD, published 2014, accessed [10.7. 2019], available online at http://sasd.sav.sk/sk/data_katalog_abs .php?id=sasd_2014003DOS 2014. 


\subsubsection{Religious practices}

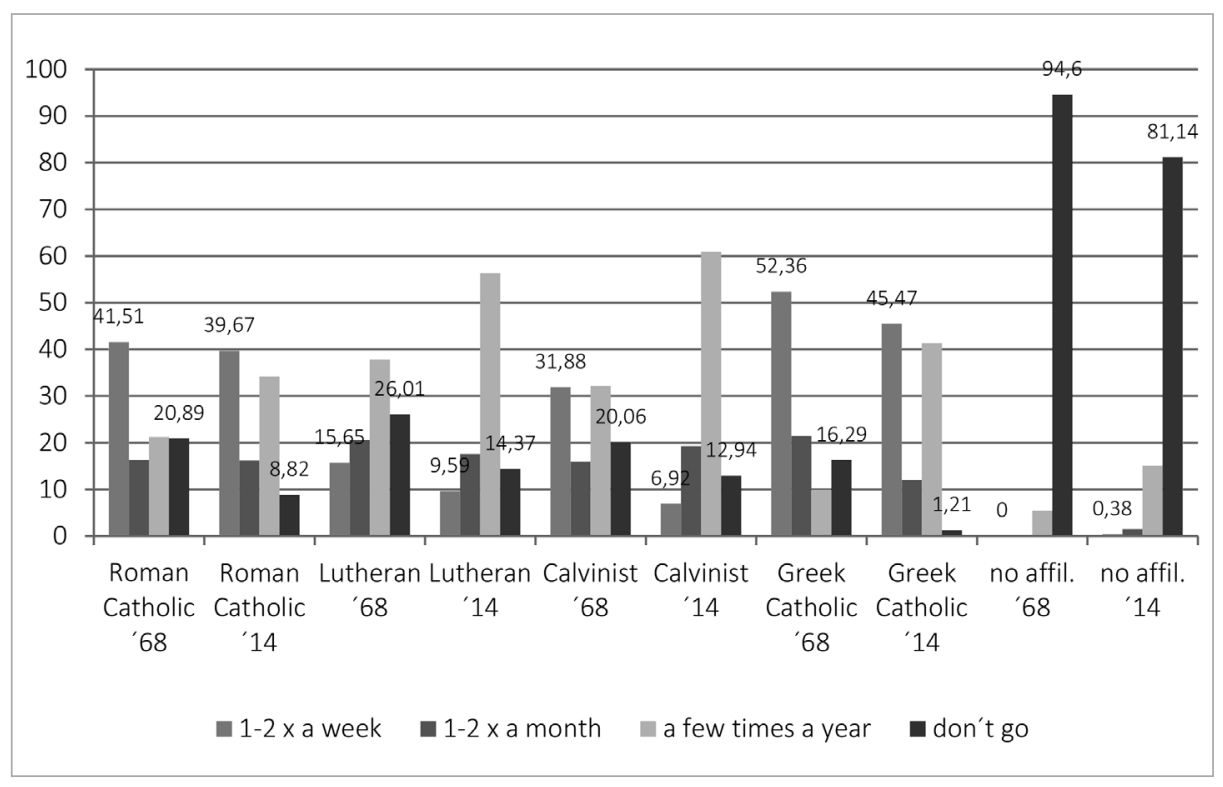

Figure 2: How often do you take part in religious ceremonies (such as mass or other church services)?

Compiled by M. Tížik 2017; SPOS 1968; DOS 2014.

From Fig. 2, it is evident that there was a significant decrease in regular church attendance mostly among Protestant churches (Lutherans and Calvinists); at the same time, there was a decline in the number of non-affiliated people who never go to church. The half-century comparison shows that members of the Greek Catholic Church still attend religious ceremonies most frequently.

When comparing various religious practices (Fig. 3 and Fig. 4), some trends are evident. Among persons who declared affiliation to religion, we can observe an increase in church-going and Bible-reading. Among those who declared not be affiliated to any religion, there has been a significant increase in church-going and other practices, except for reading religious magazines or newspapers.

\subsubsection{Religious beliefs}

'Imagine this situation: Two young people, Peter and Joseph, discuss the world today. Peter says that God does not exist, because if God existed, he would not allow things that have occurred and are occurring in the world today. Joseph disagrees with Peter and says that God exists and that people will account for their deeds before God. Peter: God does not exist, because he wouldn't allow what is happening to take place. Joseph: God exists and people will account for their deeds before God.' 


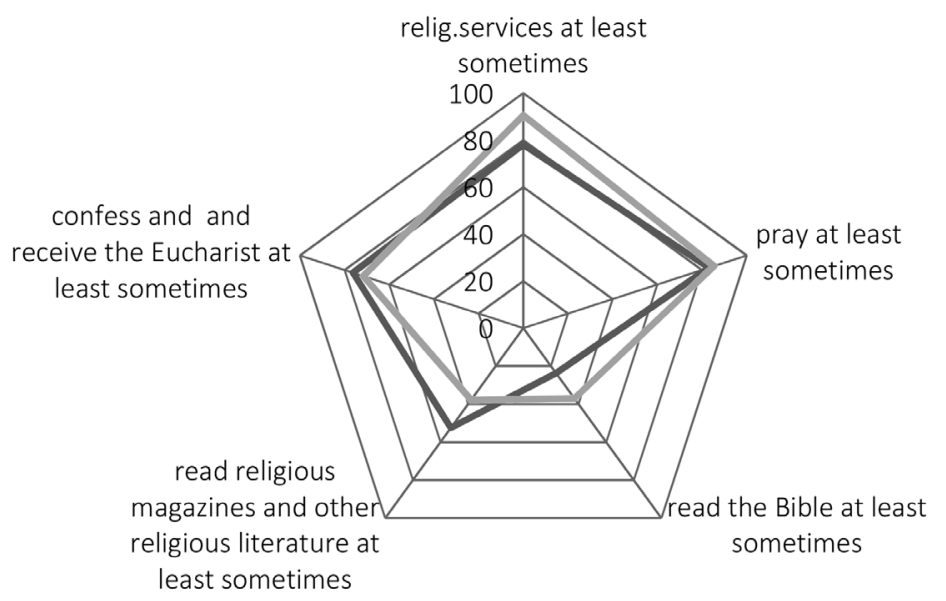

relig.affilliated '68_relig.affilliated '14

Figure 3: Comparison of basic religious practices of persons affiliated to religion. Compiled by M. Tíziik 2017; SPOS 1968; DOS 2014.

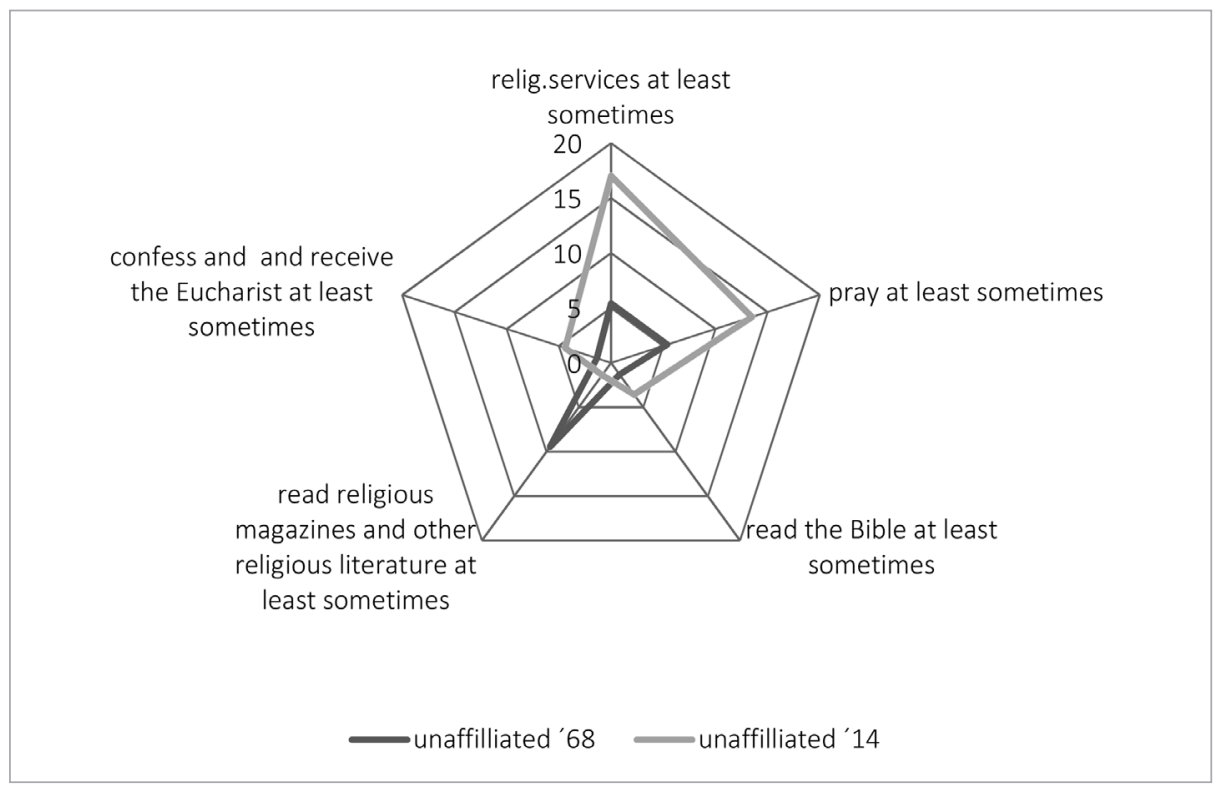

Figure 4: Comparison of basic religious practices of persons not affiliated to religion. Compiled by M. Tízik 2017; SPOS 1968; DOS 2014. 


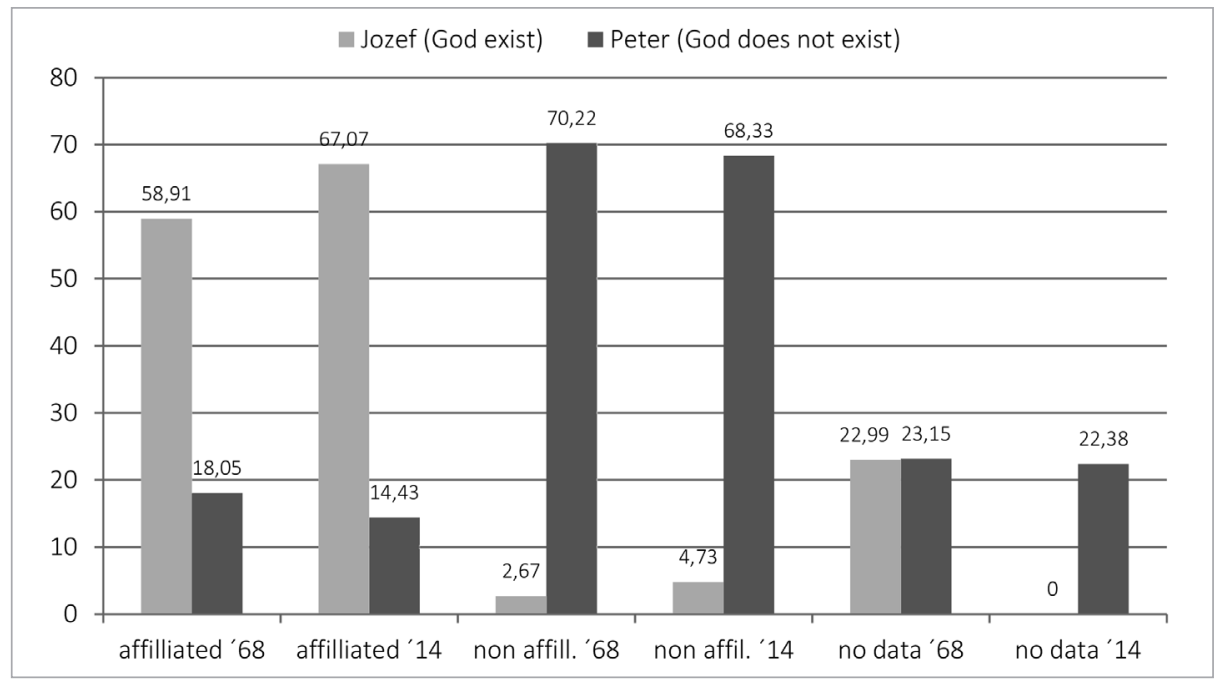

Figure 5: Belief in the existence of God.

Compiled by M. Tížik 2017; SPOS 1968; DOS 2014.

The increase in traditional religious beliefs is also confirmed by additional data from the surveys conducted in 1968 and 2014. Although there was a decrease in the number of people who declared to be affiliated to a church (and, at the same time, an increase in the number of respondents who don't believe in God), there was an increase of people who declared belief in traditional Christian principles.

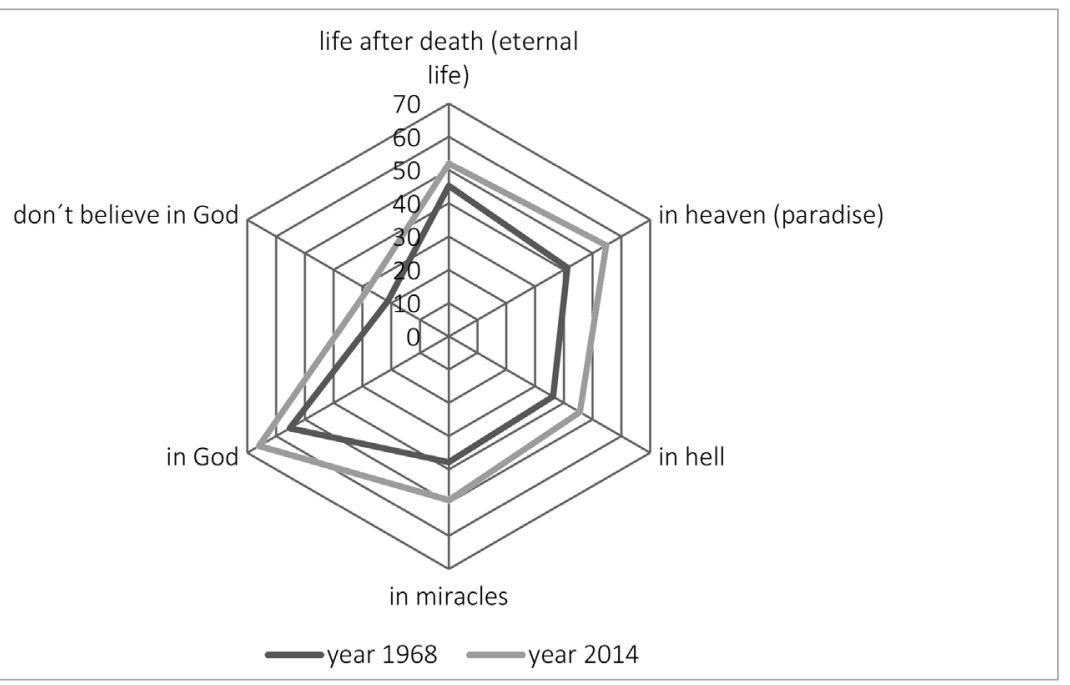

Figure 6: Comparison of basic religious beliefs in 1968 and 2014.

Compiled by M. Tížik 2017; SPOS 1968; DOS 2014. 


\section{Some Demographic Aspects of the Non-Affiliated Population in Slovakia}

Increasing proportions of religious non-affiliation are typical not only for Slovakia (it is the second most numerous segment of the population); in fact, the majority of Western societies are facing the same trend, although the periods over which these increases have occurred and the speed in which they happen do vary. Consequently, some nations now have larger unaffiliated groups, while others have much smaller ones. The recent survey revealed that, in areas where unaffiliated groups are larger, the religious 'nones' have become more distinct from the actively religious in their attitudes and behaviour. In the context of advanced secularisation, there is a greater gap between the actively religious and the non-religious when it comes to their views on family life and reproduction, with the unaffiliated being more liberal in their attitudes and less religious in their private life. Based on the analysing data from over 200 North American, European, and Oceanic country sub-regions included in the 2008 International Social Survey Programme (ISSP), with hierarchical linear models, the sociologists of religion find that, in areas where the unaffiliated form a larger proportion of the population, the differences between the actively religious and the unaffiliated in family values and personal religiosity tend to be greater. ${ }^{45}$

\subsection{Nones in Slovakia - Age composition}

As there is no data on religious affiliation for several decades, thorough demographic analyses can only be conducted for the period starting in 1991 or 2001. The census data provide quite a solid source of information, although not fully exhaustive. One of the most interesting comparisons is the age breakdown of nones compared to the rest of the population. The proportion of those aged $0-14$ in the population of nones is only $2 \%$ higher than in the whole population. It is interesting that in many - mostly rural - areas, the proportion is even lower (in many eastern Slovak districts, the proportion of 0-14 years old in the population of nones was more than $30 \%$ lower in 2001). Only in the Bratislava City and adjacent districts was the population of nones, generally speaking, younger than the entire population. The best way of depicting the age characteristics of society is by using the age pyramid method. In general, the population of nones does not differ from other populations in overall age characteristics. There are, however, differences in the relative size of the individual age groups or generations. The first notable difference is a smaller proportion of nones aged $60+$. The divergence is especially visible among women. The research outcomes of Dana Hamplová ${ }^{46}$ proved that in Czech society, religious women form the majority in all

${ }^{45}$ S. Wilkins-Laflamme, "Secularization and the Wider Gap in Values and Personal Religiosity between the Religious and Nonreligious", Journal for the Scientific Study of Religion $55(4,2016)$ : p. 717-736.

${ }^{46}$ D. Hamplová, “Náboženství a pohlaví: Proč jsou ženy zbožnější než muži?”, Sociologický časopis / Czech Sociological Review 47 (2, 2011): p. 297-323. 


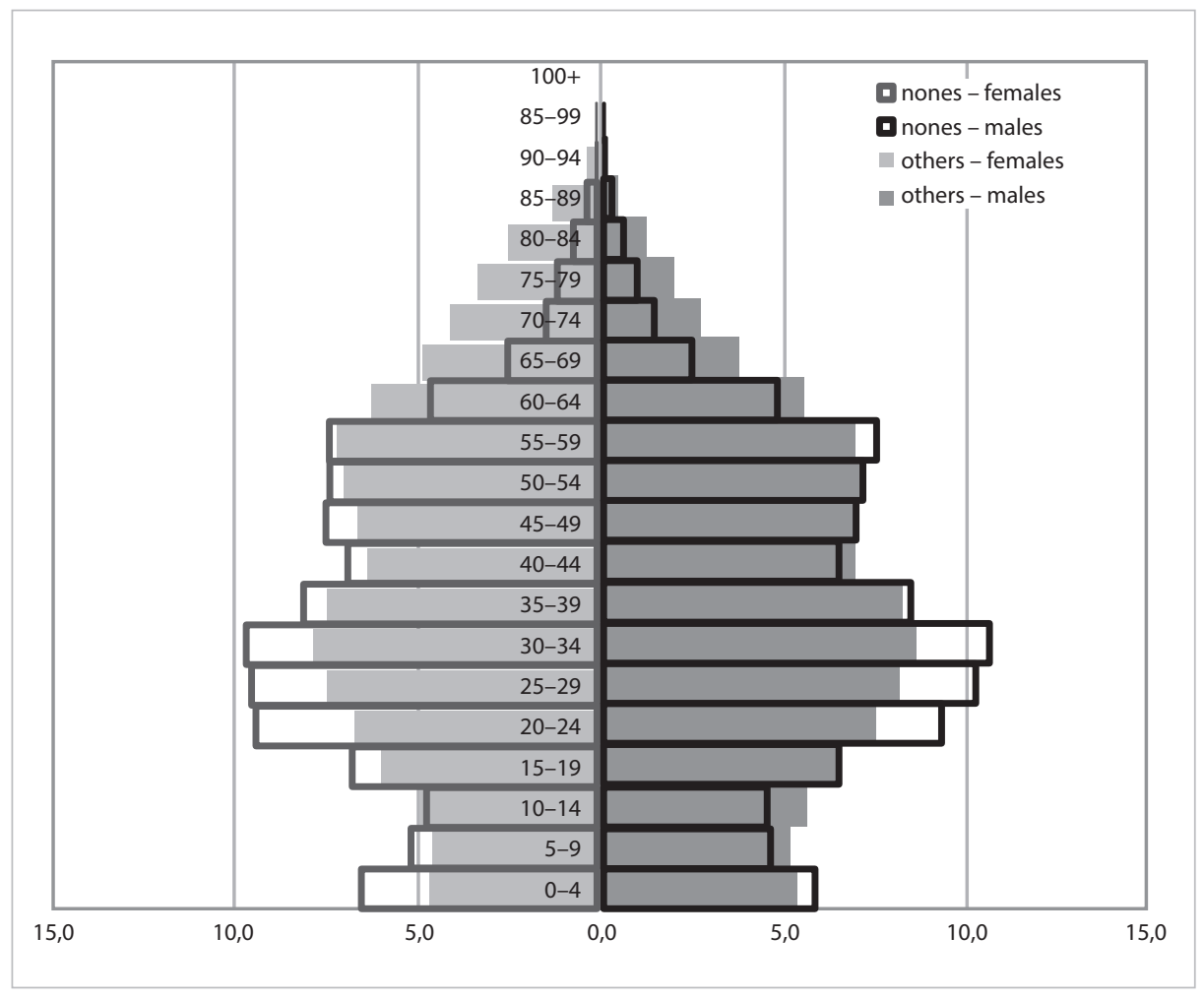

Figure 7: Age pyramid of the population of nones in Slovakia and the rest of the population. ${ }^{47}$ Source: Census 2011; compiled by J. Majo 2017.

age categories (307) and we presume that this tendency is similar in Slovak society, as well. If we take the spatial approach into account, we can see that the majority of 'older' nones live in districts covering the biggest cities (Bratislava in the west, and Košice in the east), and in north-eastern regions. These eastern Slovak regions are regions with a strong Orthodox and Greek Catholic background and, historically, with strong left-wing (especially Communists) electorate. ${ }^{48}$ If we compare the proportion of people aged $60+$ among nones against the proportion of this demographic in the rest of the population, it is always lower $(-64 \%)$, but in eastern Slovakia it is somewhat 'less' low (North-Eastern Slovakia has around -25 and $-30 \%$ ). It is not clear how to identify this group. One of the hypotheses could be the cohort of those who reacted to the forced introduction of the Orthodox Church in the disbanded Greek Catholic Church parishes. In their description of the groups of former Greek Catholic believers and their reaction to the church being disbanded, Barnovský and

47 Source: data calculated from Sč́tanie obyvatelov, domov a bytov 2011 [Census 2011].

${ }^{48}$ See e.g. V. KRIvÝ, V. Feglová and D. BALko, Slovensko a jeho regióny: Sociokultúrne súvislosti volebného správania, Bratislava: Nadácia Médiá 1996, passim. 
Pešek ${ }^{49}$ identified the "indifferent" as the largest group. These people were full of uncertainty at the time of the disbanding, had little information and interest, and, after all, they were the ones with a lower level of religious experience. One of the reactions and strategies of the members of this group could have been their withdrawal from church life. Another salient difference in the age structure is vivid among the 20-35year olds. These individuals were born on the brink of the old regime and seem to be influenced mainly by secular worldviews (needs to be verified whether this is due to Socialism and their parents mostly living in it, or general societal trends towards secularisation as they work elsewhere in Europe). The proportion of this generation at the level of nones is $27 \%$ higher than the proportion of similar generations in the rest of the population. A very high proportion of young nones can be found mostly in western Slovakian districts (Bratislava I, Komárno, Myjava, Nové Mesto nad Váhom), where it is almost $50 \%$ higher.

Most of the nones are therefore grouped in productive age groups. It is then slightly surprising that nones are not very dominant in the age group 0-14 (only 3\% higher than in the rest of the population). In a set of 43 districts out of 80 , the proportion of nones among the youngest generation is even lower than in the rest. These are, for example, regions in north-eastern Slovakia (Medzilaborce), which on one hand, had a proportion of old nones above Slovakian average, but the proportion of nones among youngsters was $56 \%$ smaller. The highest divergence can be found mainly in the districts of Bratislava City (the proportion is $60 \%$ higher).

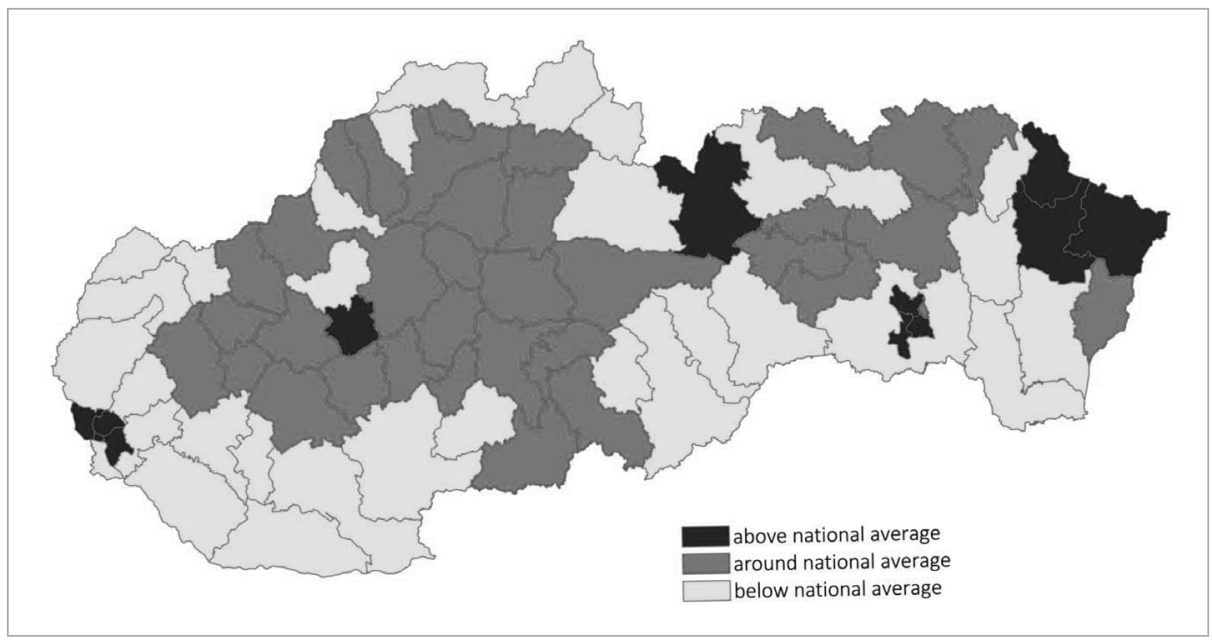

Figure 8: Proportion of nones 60+ in districts of Slovakia in $2011 .^{50}$ Source: Census 2011; compiled by J. Majo 2017.

${ }^{49}$ M. BARNOvsKÝ and J. PeŠEK, Štátna moc a cirkvi na Slovensku 1948-1953, Bratislava: VEDA SAV 1997, p. 249.

${ }^{50}$ Source: data calculated from Sč́tanie obyvatelov, domov a bytov 2011 [Census 2011]. 


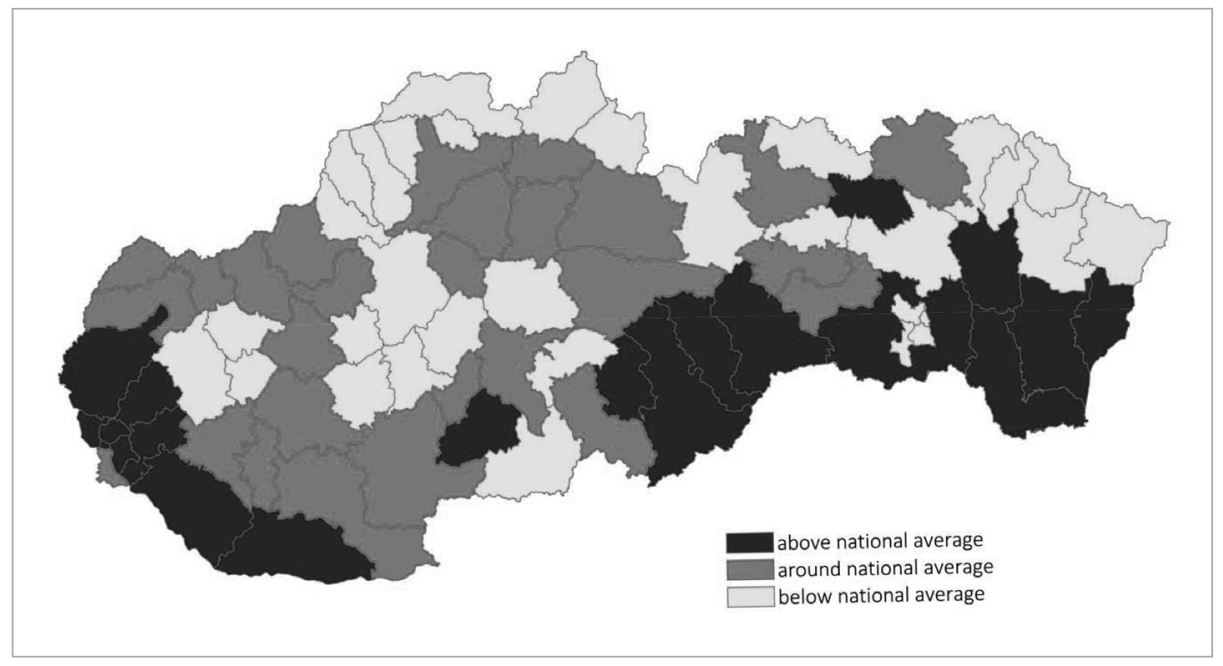

Figure 9: Proportion of nones $0-14$ in districts of Slovakia in $2011 .^{51}$

Source: Census 2011; compiled by J. Majo 2017.

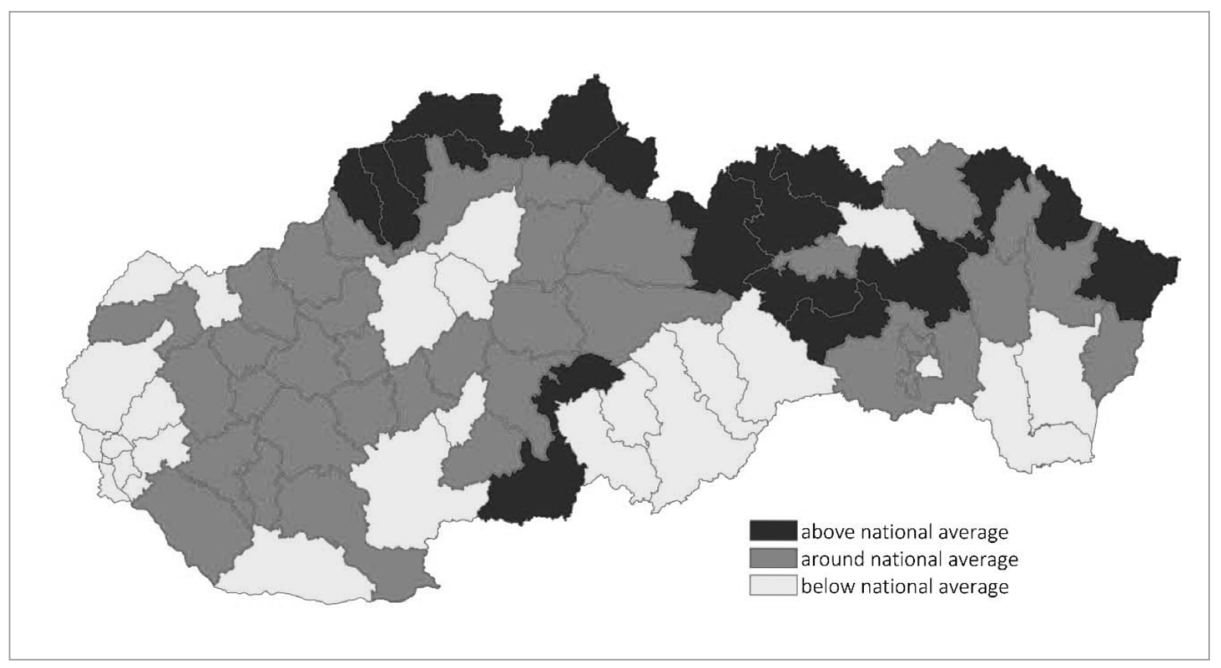

Figure 10: Nones with university education in Slovakia in $2011(\%) .^{52}$

Source: Census 2011; compiled by J. Majo 2017.

\footnotetext{
${ }^{51}$ Source: data calculated from Sčitanie obyvatelov, domov a bytov 2011 [Census 2011].

${ }^{52}$ Source: data calculated from Sč́tanie obyvatelov, domov a bytov 2011 [Census 2011].
} 


\subsection{Education level}

There is a general belief that nones or even atheists are found among the highest educated people $\mathrm{e}^{53}$ and, on the other hand, religious people are more likely to have no formal education. However, educational attainment in correlation with religion in the US did not prove, for example, that nones have the highest level of education. ${ }^{54}$ Here, the survey results proved certain positive correlations between congregational attachment and the level of education (283). The findings for Slovakian society can be easily explained by several adjacent variables - such as the rural/urban dichotomy and different concentration of nones in different regions, different age distribution within those sub-populations, employment, and so on. The distribution of the most educated people has similar spatial patterns to the distribution of people who declare themselves as nones. This is also the case in Slovakia - the proportion of nones with a university degree is almost $100 \%$ higher than in the rest of the population and, as expected, the proportion of individuals with elementary education is $44 \%$ smaller than in the rest of the population. It is interesting that the biggest gap between two sub-populations can be found not in the most secular regions (such as the urban and suburban areas of Bratislava and Košice cities), but in regions where the number of nones is not very high (especially in mostly rural and Catholic regions in northern Slovakia). The proportion of university educated nones is almost $200 \%$ higher in this case. In addition, two of the five districts of Bratislava City with quite a new immigration profile, mostly in large housing estates, have an even lower proportion of university educated nones than the rest of the population. In general, these regions have a very high share of university educated individuals, but this might mean that either the young educated generations are anchored in any of the denominations to a larger extent than their parents, or that there is just a higher proportion of those who did not declare anything (neither non-confessionalism, nor a religious affiliation).

\section{Slovakia - a Comparative Perspective}

At the very end, for the purposes of contextualising the data from censuses, surveys, and cartographic and demographic studies conducted in connection with religiosity in Slovakia during the last decades, we will briefly introduce a comparative perspective of religiosity of Slovakia, using the framework of the representative surveys carried out in Slovakia, Hungary, Czech Republic, Austria, and Poland (EVS 1990, 1999, 2008). Using these international comparative researches, we have conducted an analysis of the extent of religiosity across three dimensions - belief, membership,

${ }^{53}$ A. KeYSAR, "Religious/Nonreligious Demography and Religion versus Science: A Global Perspective", In P. ZuCKerman and J. R. Sноок (eds.), The Oxford Handbook of Secularism, Oxford: Oxford University Press 2017, p. 44-45.

${ }^{54}$ B. A. Kosmin and A. Keysar, Religion in a Free Market, Ithaca: Paramount Market Publishing 2006, p. 152-153. 


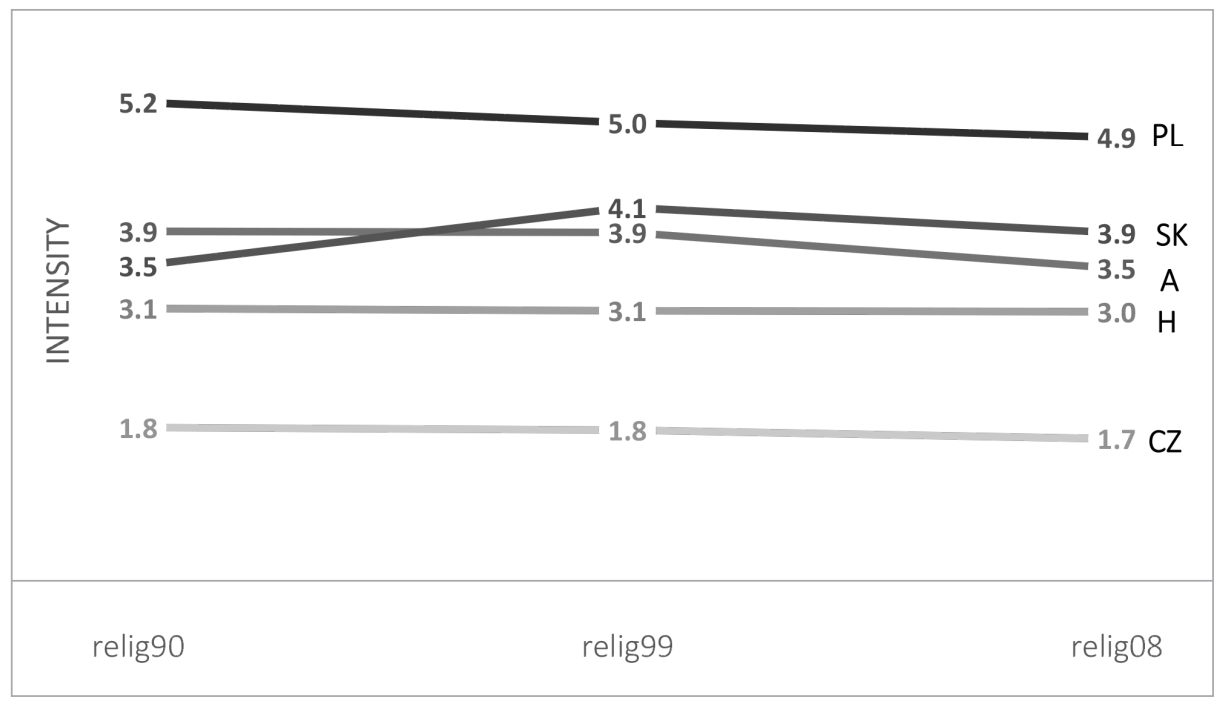

Figure 11: Religiosity level. ${ }^{55}$

Source: Podolinská, Krivý, Bahna 2013: 213; compiled by Vladimír Krivý in 2013.

and practising. ${ }^{56}$ The analyses showed that, among the analysed countries, Slovakia is the only country where religiosity became stronger when comparing 1991 and 2008 (Fig. 11).

In Poland and Austria, religiosity weakened considerably in the given period, and in Hungary and the Czech Republic it declined slightly. Yet, all these trends developed at significantly different levels of religiosity. Poland is a country with by far the highest level of religiosity, while the Czech Republic is known for its low degree of religiosity. The third group of countries, the 'group in the middle', is represented by Slovakia, Austria, and Hungary. The closest country to Slovakia in terms of the average level of religiosity is Austria, followed by Hungary. Following the same criterion, the most distant country is the Czech Republic.

During the past almost 20 years, the share of fully religious people (people with the highest level of religiosity) decreased in three countries: there was a dramatic decline in Poland, and a slight decrease in Austria and Hungary. In the Czech Republic and Slovakia, these shares were identical at the beginning and at the end of the given period - though in a different way in both countries. The shares of fully secular people and people with a very low degree of religiosity are the highest in the Czech Republic, followed by Hungary and Slovakia (Table 4).

${ }^{55}$ Compiled by Vladimír Krivý in 2013. T. Podolinská, V. KRIvÝ and M. BAHna, "Religiozita: Slovensko a jeho susedia”, In V. Krivý (ed.), Ako sa mení slovenská spoločnost', Sociologický ústav 2013, p. 213.

${ }^{56}$ See T. Podolinská, KrivÝ and BAHna, “Religiozita: Slovensko a jeho súsedia”, p. 181-256. 
Table 4: Religiosity level. ${ }^{57}$

\begin{tabular}{l|l|l|l}
\hline Country & \multicolumn{4}{|l}{ Level/intensity of religiosity in } \\
\hline & 1991 & 1999 & 2008 \\
\hline Poland (PL) & 5.2 & 5.0 & 4.9 \\
\hline Slovakia (SK) & 3.5 & 4.1 & 3.9 \\
\hline Austria (A) & 3.9 & 3.9 & 3.5 \\
\hline Hungary (H) & 3.1 & 3.1 & 3.0 \\
\hline Czech Rep. (CZ) & 1.8 & 1.8 & 1.7 \\
\hline
\end{tabular}

In each of these five countries, the inter-dimensional differences (belief, membership, practising) diverged in the period 1991-2008. The general pattern is the following: belief as the strongest dimension, membership in the middle, and practising as the weakest dimension. While all three dimensions weakened in Poland and Austria in the given period, Slovakia saw an opposite tendency - the strengthening of all three dimensions. Overall, religiosity increased with regard to the belief dimension in three countries, declined with regard to the membership dimension in four countries, and again declined with regard to the practising dimension in three countries (Fig. 12).

Practising turned to be clearly the weakest point of religiosity. In all five countries, private (individual) practice of religiosity is present to a much greater extent than public (collective) practice. Poland is an exception in this respect, as the level of public practice in this country is greater than the occurrence of private practice in all four other countries. Overall, the phenomenon of smaller practice can lead to stronger religiosity based on belief and private practising in future generations, but it can also continue weakening private practising and belief as such.

As far as religious rituals are concerned, the norm has become increasingly accepted among young people and less and less accepted among older people throughout the past almost 20 years. In general, there has been an inter-generational convergence in the acceptance of baptism, church marriage and church funeral (Fig. 13).

Finally, the proportion of consumption of non-Christian ideas and so-called alternative spirituality with regard to the level of religiosity was surveyed as well. In Slovakia, non-Christian and non-conformist ideas (corresponding to 'alternative spirituality' to a certain extent) are more frequent among people with a higher degree of religiosity. Instead of seeking an 'alternative' to traditional religiosity, we can rather speak about an acceptance of an 'alternative' in the framework of traditional religiosity. At the level of the individual, this can be seen as detraditionalization or even individualisation of (personal) religiosity.

${ }^{77}$ Compiled by Tatiana Zachar Podolinská in 2017, based on calculations by Vladimír Krivý in 2013. Podolinské, Krivý and BAHna, “Religiozita: Slovensko a jeho susedia”, p. 181-256. 


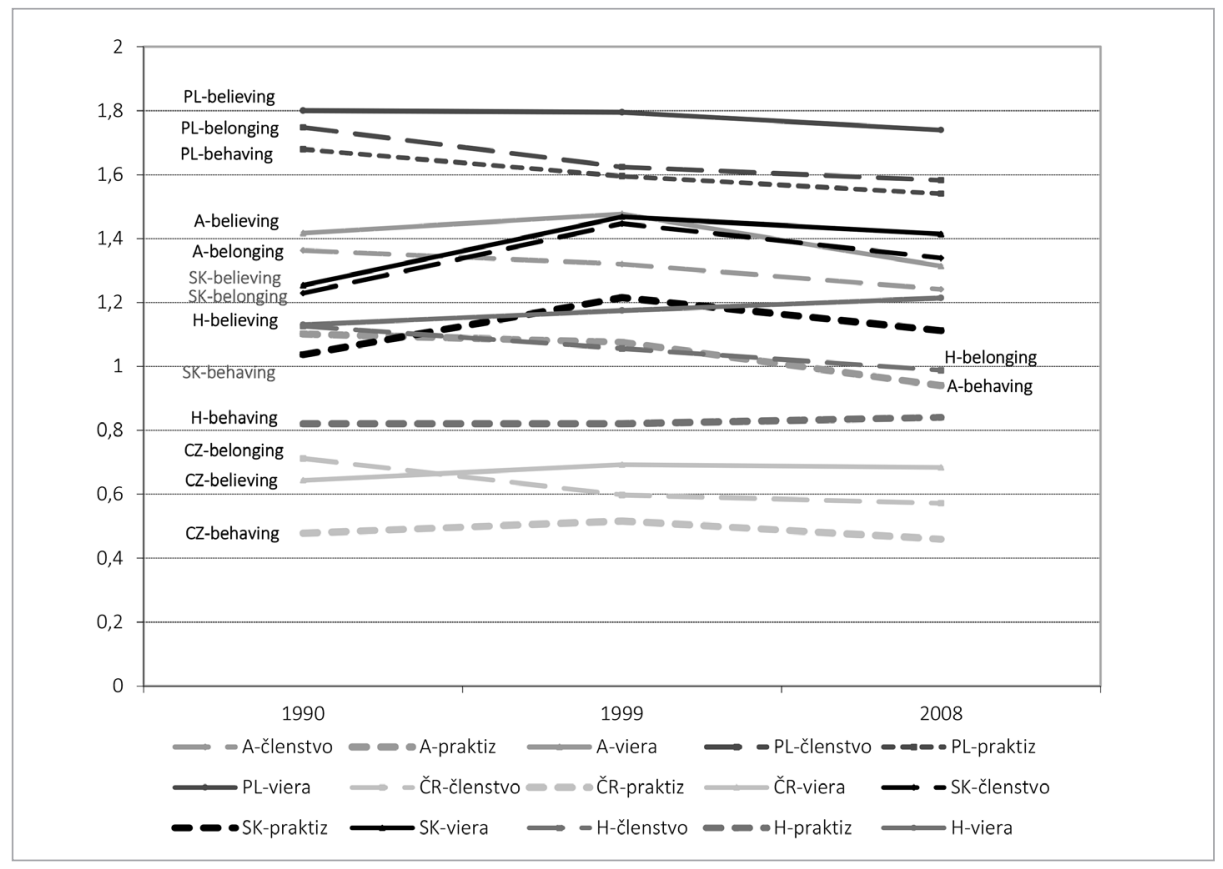

Figure 12: Dimensions of religiosity: believing, practising, behaving. ${ }^{58}$ Source: Podolinská, Krivý, Bahna 2013: 217; compiled by Vladimír Krivý in 2013.

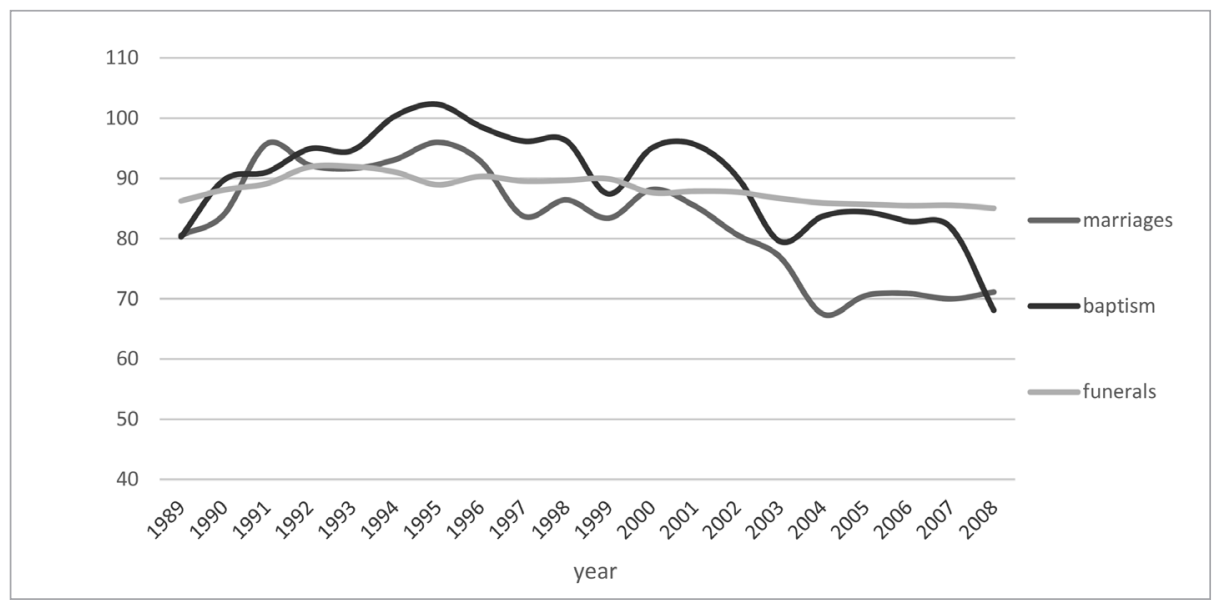

Figure 13: Religious rituals 1989-2008. ${ }^{59}$

Source: Podolinská, Krivý, Bahna 2013: 235; compiled by Vladimír Krivý in 2013.

${ }^{58}$ Compiled by Vladimír Krivý in 2013. PodolinsKÁ, KrivÝ and BAHNA, "Religiozita: Slovensko a jeho súsedia”, p. 181-256.

${ }^{59}$ Compiled by Vladimír Krivý in 2013. Podolinská, Krivý and Bahna, "Religiozita: Slovensko a jeho súsedia”, p. 235. 


\section{Conclusions}

The societal, political, and international changes during more than 20 years of the Slovak Republic suggest several basic conclusions. Religion can in some situations be an important component for the mobilisation of collective identity. As the effect of the integration of religion into the symbolical character of the State, there has been an increase in the spreading of traditional Christian beliefs. In this sense, religion serves as a kind of compensatory legitimizing tool in cases where few other symbolic sources of national identity are available in the collective memory or in the principles of institutional functioning. Nevertheless, even though religion helps preserve the homogeneity of society in "critical" situations, this does not manifest itself as increased in religious affiliation. There is a certain increase in the activity of the Slovak population, but only in some basic religious practices.

In the case of the Slovak Republic, the State's symbolic and legislative privileging of Christian actors, particularly the Catholic Church and partly also the Lutheran Church, and the integration of these actors into the symbolic character of the State, has increased throughout the last two decades. Representatives of the Catholic Church have become important actors in political and public debates. In addition, the Catholic Church has become a hegemonic leader in establishing the basic principles of the regulation and functioning of religious life in Slovakia. The strengthening of their economic positions and the symbolic favouring of traditional Churches are strong factors that enable reproduction of the principles of dominant Churches but also of the field of power, which dates back to the formation of the Slovak Republic.

However, the 'traditional' religiosity landscape in Slovakia has also faced a rapid increase in the number of non-affiliated persons and persons not willing to respond to questions concerning their religiosity over the past decades. The population of nones in the Slovak Republic has many specificities, although the differences compared to the rest of the population are not as significantly different, as one would have expected. The age profile follows general trends in society with the highest percentage on nones among the productive age group, especially around the age of 30 and younger. The age groups around 30 are very strong in the western part of the country and in Bratislava. On the other hand, older age groups are present slightly above the national average in eastern Slovakia, and mostly rural districts, possibly reflecting its past evolution. Attained education seems to be relevant mainly through the higher proportion of college/university degree holders among nones, and the small proportion of individuals with elementary school education. The concentration of nones with higher education is significantly higher in regions with low imprints of secularisation.

Alongside the process of "visible secularisation" of Slovak society, we are experiencing a process of transformation and adaptation of traditional Christianity. Current Christianity in Slovakia is a multi-coloured mixture of traditional, post-traditional, and non-traditional religiosity. Nevertheless, when comparing the overall level of 
religiosity in Slovakia with its neighbours (Poland, Hungary, Czech Republic and Austria), Slovakia belongs to the "group in the middle", represented by Slovakia, Austria, and Hungary. The closest country to Slovakia in terms of the average level of religiosity is Austria, followed by Hungary. Following the same criterion, the most distant country is the Czech Republic. Among these, Slovakia is the only country where overall religiosity increased (1991-2008) in all its dimensions - believing, belonging and practising.

Practising clearly turned out to be the weakest point of religiosity. Private (individual) practising of religiosity is present to a much greater extent than public (collective) practising in Slovakia. Overall, the phenomenon of smaller practice can lead to stronger religiosity based on belief and private practising in future generations, but it can also continue weakening private practising and belief as such.

In Slovakia, non-Christian and non-conformist ideas (corresponding to "alternative spirituality" to a certain degree) are more frequent among people with a higher degree of religiosity. Instead of seeking an "alternative" to traditional religiosity, we can rather speak about an acceptance of the "alternative" in the framework of traditional religiosity. At the level of the individual, this can be considered detraditionalization or even individualisation of (personal) religiosity.

In general, we can conclude that churches and other religious or faith-based institutions in Slovakia should be aware of the multi-coloured landscape of modern believers and modify the dialogue according to the specific traits of the respective strata of believers. In this regard, the flexible and non-orthodox approach of "non-traditional" churches is sometimes more fitting the needs of post-traditional and non-traditional believers. Two options are available in this respect: 1) to develop a kind of experiment and promote an intensive dialogue on the "margins" of "orthodoxy" and "normativity" (sometimes called post-Christianity), or 2) to guard the door and get rid of all "free passengers" (even more orthodox Christianity).

\section{Acknowledgements}

The core of this text was created as a result of The Future of Religious Faith from Central European Perspective project funded by the Templeton Foundation (www.budouc nostnabozenstvi.cz).

The paper was further re-elaborated and finished within the scientific project VEGA 2/0060/19 Ethnographic Research of Non-Religion and Secularism in Modern Slovak Society (Life-Trajectories and Stories) and the scientific project GAČR 19-08512S Dynamics of the churches' moral economies in the Czech Republic and Slovakia in the context of restitutions and separation of church and state. 


\section{REFERENCES}

BARnovskÝ, M., "Gréckokatolícka cirkev a slovensko-rusínsko/ukrajinské vztahy v 20. storočí”, In TATiAnA IVANTYŠYNová (ed.), Národ - cirkev - štát, Bratislava: Spoločnost' pre dejiny a kultúru strednej a východnej Európy, Centrum pre európsku politiku, Historický ústav SAV 2007, p. 200-201.

BARnovskÝ, M., and J. PešEK, Štátna moc a cirkvi na Slovensku 1948-1953, Bratislava: Veda SAV 1997, 311 p.

BEŇUŠKovÁ, Z., "Náboženstvo ako integračný a dezintegračný faktor v lokálnom dedinskom spoločenstve”, In Tatiana IvantyšYnová (ed.), Národ - cirkev - štát, Bratislava: Spoločnost pre dejiny a kultúru strednej a východnej Európy, Centrum pre európsku politiku, Historický ústav SAV 2007, p. 235-252.

BouRdiEu P., "Genèse et structure du champ religieux", Revue française de sociologie, $12(3,1971):$ p. 295-334.

Buchler, R. J., and G. FAtranová, “Z histórie slovenského židovstva”, In Encyklopédia židovských náboženských obcí A-K, vol. 1, Bratislava, SNM, Múzeum židovskej kultury 2009.

CoRAnIČ, J., Dejiny gréckokatolíckej cirkvi na Slovensku v rokoch 1918-1939, Prešov: Prešovská univerizta, Gréckokatolícka teologická fakulta 2013, 415 p.

ČEPLíkovÁ, M. (s.d.), Postavenie cirkví a náboženských spoločností v právnom poriadku Slovenskej republiky [online], accessed [26.8.2019], available online at http://spcp.prf .cuni.cz/15-20/19-cepli.htm].

IvantyšYnová, T. (ed.), Národ - cirkev - štát, Bratislava: Spoločnost pre dejiny a kultúru strednej a východnej Európy, Centrum pre európsku politiku, Historický ústav SAV 2007,266 p.

IvantyšYnOvá, T., “Od luteránstva k pravosláviu”, In TATiAna IvantyšYnová (ed.), Národ - cirkev - štát, Bratislava: Spoločnost pre dejiny a kultúru strednej a východnej Európy, Centrum pre európsku politiku, Historický ústav SAV 2007, p. 41-48.

FEKETE, Š., "Rozloženie vierovyznaní na Slovensku podl'a sčítania ludu z r. 1930 - mapa”, In НroмádKA, J., V̌seobecný zemepis Slovenska, Bratislava: Slovenská akadémia vied a umení 1943.

Halas, FrantišEK X., “Sekularizace v první Československé republice a Svatý stolec”, In Tatiana Ivantyšynová (ed.), Národ - cirkev - štát, Bratislava: Spoločnost' pre dejiny a kultúru strednej a východnej Európy, Centrum pre európsku politiku, Historický ústav SAV 2007, p. 100-118.

HamplovÁ, D., “Náboženství a pohlaví: Proč jsou ženy zbožnější než muži??, Sociologický časopis / Czech Sociological Review 47 (2, 2011): p. 297-323.

Holák, M., "Politický katolicizmus na Slovensku 1918-1939”, In Tatiana IvantyšYnová (ed.), Národ - cirkev - štát, Bratislava: Spoločnost pre dejiny a kultúru strednej a východnej Európy, Centrum pre európsku politiku, Historický ústav SAV 2007, p. 164-81.

Hubenák, L., "Církve a náboženské společnosti v Československu 1918-1938”, Prometheus - Časopis pre občiansku spoločnost'a humanismus III (4, 2007): p. 23-25.

HolEc, R., "Slovenskí katolíci medzi národom a štátom”, In TATiAna IvanTYŠYNová (ed.), Národ - cirkev - štát, Bratislava: Spoločnost pre dejiny a kultúru strednej a východnej Európy, Centrum pre európsku politiku, Historický ústav SAV 2007, p. $57-75$.

JudÁk, V., and Š. PoláčıK (eds.), Atlas katolíckej cirkvi na Slovensku. Bratislava: Lúč 2005, 269 p.

Kirschbaum, S. J., A History of Slovakia: The Struggle for Survival, New York: Palgrave Macmillan 1995, 350 p. 
Keysar, A., "Religious/Nonreligious Demography and Religion versus Science: A Global Perspective”, In P. Zuckerman and J. R. SHook (eds.), The Oxford Handbook of Secularism, Oxford: Oxford University Press 2017, pp. 40-54.

Kodajová, D., “Jur Janoška v evanjelickej cirkvi a v národe”, In Tatiana IvantyšYnová (ed.), Národ - cirkev - štát, Bratislava: Spoločnost pre dejiny a kultúru strednej a východnej Európy, Centrum pre európsku politiku, Historický ústav SAV 2007, pp. 76-87.

KMĚ̌, N., "Katolícka cirkev a ludovodemokratický štát", In TATIANA IvanTyšYnová (ed.), Národ - cirkev - štát, Bratislava: Spoločnost pre dejiny a kultúru strednej a východnej Európy, Centrum pre európsku politiku, Historický ústav SAV 2007, pp. 217-234.

Kosmin, B. A., and A. Keysar, Religion in a Free Market, Ithaca: Paramount Market Publishing 2006, 299 p.

KowALSKÁ, E., Evanjelické a.v. společenstvo: Hlavné problémy jeho vývoja a fungovania $v$ spoločnosti, Bratislava: VEDA SAV 2001, 220 p.

KRIVÝ, V., "Hodnotové orientácie a náboženské prejavy slovenskej verejnosti v 90. rokoch”, Sociológia 33 (1, 2001): p. 7-45.

KRIVÝ, V., Kolektívne identity na súčasnom Slovensku, Bratislava: ÚEt SAV, SÚ SAV 2004, $90 \mathrm{p}$.

KRIVÝ, V., V. Feglová and D. BALKo, Slovensko a jeho regióny: Sociokultúrne súvislosti volebného správania, Bratislava: Nadácia Médiá 1996, 414 p.

KRIVÝ, V. (ed.), Ako sa mení slovenská spoločnost', Bratislava: Sociologický ústav SAV 2013, $417 \mathrm{p}$.

KvasničKovÁ, A., “Náboženský život”, In J. Sopóci et al., Slovensko v devät'desiatych rokoch, osem pohl'adov, Bratislava: Univerzita Komenského 2003, p. 229-308.

Kusendová, D., and M. BEnžA (eds.), Historický atlas Evanjelickej cirkvi augsburgkého vyznania na Slovensku, Liptovský Mikuláš: Tranoscius 2011, 176 p.

Lexicon universorum regni Hungariae locorum populosorum anno 1773 officiose confectum, Budapest: V. Hornyánszky 1920 (reprint), 335 p.

LiptÁк, L., Changes of Changes: Society and Politics in Slovakia in the 20th Century, Bratislava: Historical Institute of Slovak Academy of Sciences 2002, 167 p.

Lopatková, Z., Cirkevné dejiny stredovekého Slovenska, Trnava: Filozofická fakulta Trnavskej univerzity 2013, $77 \mathrm{p}$.

LUPČo, M., "Religiozita pravoslávnych veriacich v slovenskej spoločnosti”, Kultúrne dejiny $(1,2011):$ p. $88-107$.

Majo, J., "Vybrané charakteristiky transformácie religiozity na Slovensku v rokoch 1950-2001 vo vztahu k sekularizácii”, Geografický ćasopis 65 (3, 2013): p. 217-234.

MAjo, J., and D. KusEndová, "Mapy národnostnej a náboženskej štruktúry obyvatel'stva Slovenska podl'a geografického lexikónu Uhorska (1851)”, In Historické mapy: Zborník referátov z vedeckej konferencie, Bratislava: Kartografická spoločnost' SR, Geografický ústav SAV 2005, p. 98-101.

Majo, J., and D. KusEndovÁ, “Etnické a náboženské pomery Slovenska v polovici 19. storočia podl'a geografického slovníka Uhorska od Eleka Fényesa z roku 1851”, Historický časopis 55 (4, 2007): p. 739-748.

Majo, J., D. Kusendová and M. BenžA (eds.), Náboženský atlas Slovenska, Bratislava: DAJAMA 2015, 64 p.

Michela, M., "Svätoštefanská tradícia na Slovensku v medzivojnovom období", In TATIANA Ivantyšynová (ed.), Národ - cirkev - štát, Bratislava: Spoločnost pre dejiny a kultúru strednej a východnej Európy, Centrum pre európsku politiku, Historický ústav SAV 2007, p. 119-127. 
OčovskÝ, Š., “Vývoj religióznej štruktúry obyvatel'stva na Slovensku”, Geografický časopis 45 (3, 1993): p. 217-234.

PEŠEK, J., “Slovensko-mad'arské spory v reformovanej krestanskej cirkvi na Slovensku po druhej svetovej vojne”, In TATiana IvantyšYnová (ed.), Národ - cirkev - štát, Bratislava: Spoločnost pre dejiny a kultúru strednej a východnej Európy, Centrum pre európsku politiku, Historický ústav SAV 2007, p. 185-199.

Podolinská, T., "Religiozita v dobe neskorej modernity: Prípad Slovensko”, Sociální studia (3-4, 2008): p. 51-84.

PodolinskÁ, T., “Quo vadis Domine?” K typológii súčasných náboženských a duchovných identít na Slovensku”, Slovenský národopis 55 (2, 2007): p. 135-158.

Podolinská, T., V. KRIVÝ and M. Bahna, "Religiozita: Slovensko a jeho susedia”, In V. Krivý (ed.), Ako sa mení slovenská spoločnost', Sociologický ústav 2013, p. 181-256.

PoláčIK, Š., Atlas cirkví, náboženských spoločností a religiozity Slovenska, Bratislava: Chronos 2000, $150 \mathrm{p}$.

PURš, J., Atlas of Czechoslovak History (Atlas of Czechoslovak History). Praha: Ústřední správa geodézie a kartografie, 196, 238 p.

Sokolová, M., "Postoj evanjelickej cirkvi augsburského vyznania k otázke rozšírenia českobratskej cirkvi evanjelickej na územie Slovenska po roku 1918”, In TATiANA IVANTYŠYnOvá (ed.), Národ - cirkev - štát, Bratislava: Spoločnost' pre dejiny a kultúru strednej a východnej Európy, Centrum pre európsku politiku, Historický ústav SAV 2007, p. 128-143.

SvátKovÁ, I., "Reformovaná cirkev v 1918-1939 na Slovensku”, In Tatiana IVANTYŠYNOvÁ (ed.), Národ - cirkev - štát, Bratislava: Spoločnost' pre dejiny a kultúru strednej a východnej Európy, Centrum pre európsku politiku, Historický ústav SAV 2007, p. 144-153.

ŠKvarna, D., "Dva svety v jednej církvi”, In Tatiana IvantyšYnová (ed.), Národ cirkev - štát, Bratislava: Spoločnost' pre dejiny a kultúru strednej a východnej Európy, Centrum pre európsku politiku, Historický ústav SAV 2007, p. 33-40.

SvátKová, I., "Reformovaná cirkev na Slovensku v rokoch 1918-1938”, In TATIANA IvANTYŠYnOvá (ed.), Národ - cirkev - štát, Bratislava: Spoločnost' pre dejiny a kultúru strednej a východnej Európy, Centrum pre európsku politiku, Historický ústav SAV 2007, p. 144-153.

ŠvagrovskÝ, Š., "Vznik pravoslávia v Čechách a na Morave a biskup Gorazd”, In TATIANA IVANTYŠYNOVÁ (ed.), Národ - cirkev - štát, Bratislava: Spoločnost' pre dejiny a kultúru strednej a východnej Európy, Centrum pre európsku politiku, Historický ústav SAV 2007, p. 154-163.

ŠProcha, B., and P. TIŠLIAR, Lexikóny obcípre územie Slovenska I.: Vybrané úradné lexikóny z rokov 1920-2002, Bratislava: Infostat 2009, 158 p.

TížıK, M., K sociológii novej religiozity, Bratislava: Univerzita Komenského 2006, 392 p.

Tížıx, M., "Out of Civil Religion in Slovakia after 1993”, In E. RÉvaY and M. ToмkA (eds.), Church and Religious Life in Post-Communist Societies, Pázmány Társadalomtudomány 7, Budapest: Piliscsaba 2007, p. 183-207.

Tížıк, M., Náboženstvo vo verejnom živote na Slovensku: Zápasy o ideový charakter štátu a spoločnosti, Bratislava: Sociologický ústav SAV 2011, 423 p.

TÍžIK, M., "Religion and National Identity in an Enlarging Europe”, In Franz HölLINGER and Markus Hadler (eds.), Crossing Borders, Shifting Boundaries: National and Transnational Identities in Europe and Beyond, Frankfurt-on-Main: Campus Verlag 2012, p. 101-123.

TížIK, M., "Religion and the State after the Fall of State Socialism in Central and Eastern Europe”, In Religious Diversity Today: Experiencing Religion in the Contemporary World, 
vol. 3: Religion Transforming Societies and Social Lives, Santa Barbara: Praeger 2015, p. 169-202.

Tomka, M., Church, State, and Society in Eastern Europe, Washington: The Council for Research in Values and Philosophy 2005, 237 p.

TRAPL, M., ““Kulturní boj” v nástupnických státech Rakousko-Uherska po roce 1918 s hlavním zřetelem k českým zemím”, In Tatiana IvantyšYnová (ed.), Národ cirkev - štát, Bratislava: Spoločnost pre dejiny a kultúru strednej a východnej Európy, Centrum pre európsku politiku, Historický ústav SAV 2007, p. 91-99.

Wilkins-Laflamme, S., "Secularization and the Wider Gap in Values and Personal Religiosity between the Religious and Nonreligious", Journal for the Scientific Study of Religion 55 (4, 2016): p. 717-736.

\section{DATA SOURCES}

For Censuses in Slovak Republic (Czechoslovakia) 1930, 2001, and 2011 see:

Majo, J., and M. Tížıx, Prehl'ad konfesionality obyvatel'stva obcí Slovenska v sčitaniach 1869-2011 [Denominational breakdown of the population of communes in Slovakia 1869-2011] [online], SASD, EVS 1991, accessed [10.7.2019], available online http://sasd .sav.sk/sk/data_katalog_abs.php?id=sasd_2011002

Štatistický lexikón obcív krajine Slovenskej, Praha: Štátny úrad štatistický 1936, 249 p.

Sčitanie obyvatel'ov, domov a bytov 2001. Bývajúce obyvatel'stvo podl'a pätročných vekových skupín, podl'a pohlavia a náboženského vyznania: Sčitanie obyvatel'ov, domov a bytov, Bratislava: Štatistický úrad 2001.

Sčitanie obyvatel'ov, domov a bytov 2011. Obyvatel'stvo SR podl'a náboženského vyznania, pohlavia a veku: Sčitanie obyvatelov, domov a bytov 2011, Bratislava: Štatistický úrad SR 2011.

\section{OTHER}

Právne postavenie a ekonomické zabezpečenie registrovaných cirkví [online], Ministerstvo kultúry Slovenskej republiky, accessed [16.8.2019], available online at http:// www.culture.gov.sk/vdoc/250/pravne-postavenie-a-ekonomicke-zabezpecenie -registrovanych-cirkvi-a-nabozenskych-spolocnosti-2f.html.

Slovenský archív sociálnych dát [online] [Slovak Archive of Social Data], accessed [10.7.2019], available online at http://sasd.sav.sk/sk.

International Social Survey Programme [online], accessed [10.7.2019], available online at http: //www.issp.org.

EVS - Výskum európskych hodnôt 1991 [EVS - European Values Study 1991]

[online], SASD, EVS 1991, accessed [10.7.2019], available online http://sasd.sav.sk/sk /data_katalog_abs.php?id=sasd_1991001.

EVS - Výskum európskych hodnôt 1999 [EVS - European Values Study 1999] [online], SASD, EVS 1999, accessed [10.7.2019], available online

http://sasd.sav.sk/sk/data_katalog_abs.php?id=sasd_1999002.

EVS - Výskum európskych hodnôt 2008 [EVS - European Values Study 2008]

[online], SASD, EVS 2008, accessed [10.7.2019], available online http://sasd.sav.sk/sk /data_katalog_abs.php?id=sasd_2008001.

ISSP Náboženstvo 1998 [ISSP Religion 1998] [online], SASD, ISSP 1998, accessed

[10.7.2019], available online

http://sasd.sav.sk/sk/data_katalog_abs.php?id=sasd_1998001. 
Kolektívne identity na súčasnom Slovensku 2003 [Collective Identities in Contemporary Slovakia 2003] [online], SASD, accessed [10.7.2019], available online http://sasd.sav.sk /sk/data_katalog_abs.php?id=sasd_2003001

O svetonázorových postojoch obyvatel'ov Slovenska 1968 [Word View Attitudes in Slovakia 1968] [online], SASD, SPOS 1968, accessed [10.7.2019], available online http://sasd.sav .sk/sk/data_katalog_abs.php?id=sasd_1968002.

Demokratickost'a občania na Slovensku [Democracy and Citizens in Slovakia], SASD, published 2014, accessed [10.7.2019], available online at http://sasd.sav.sk/sk/data _katalog_abs.php?id=sasd_2014003. 